\title{
CLINICAL STUDY ON THE LABYRINTHINE DISORDER
}

- Especially on the Vestibular Function of Sudden

Loss of Cochleo-Vestibular Function -

\section{By}

MTснніко NOZUE

\section{From the Deartment of Oto-Rhino-Laryngology, Faculty of Medicine,} University of Tokyo. (Director: Prof. I. Kirikae)

Vestibular function and of principle cause of sudden loss of cochleo-vestibular function which did not occcure repeatedly was studied.

The results were as follows:

1) Many patients with this disorder seemed to have vasomotor disturbances showing sudden flushig and chille, headaches and stiff shoulders. The next main factor was allergic diathesis. Chiefly they complaind of mental and physical fatigue and cold. A few cases showed attacks after extraction of teeth and under a drier for permanentwave.

Furthermore some cases accompanied with acoustic tumor, subarachnoideal bleeding and cranial polyneuritis, were seen. Two cases, in which numerous Dihydrostreptmycin injections had been carried out, attacks appeared shortly after the chest surgery under general anesthesia.

2) Nystagmus in 91 cases out of 113 cases was found. Abnormal nystagmus were found especially by positional and positioning nystagmus test. Many kinds of nystagmus, namely direction fixd, direction changing, horizontal, rotatoric and vertical nystag. mus were found. That findings of nystagmus had very important meaning for the diagnosis of the affected area was also emphasized.

3) In Caloric Test $71 \%$ out of 113 cases were CP. This test is also important for the diagnosis of the degree of lesion and of the affected area. When there is no response of the Caloric Test we must differentiate it from acoustic tumor.
4) In Optokinetic Nystagmus (OKN) Test, examined by Optokinetic Pattern (OKP) Test, many cases showed peripheral type, but some cases showed semicentral and central type.

5) Many cases showed laterality in Optokinetic After Nystagmus (OKAN) Test. This finding is useful for the diagnoss of DP.

On the other hand rotatoric test is not useful for the diagnosis of the side and degree of the lesin.

6) In Counterrolling Test of the eye, many cases showed abnormal value at the affected side. This finding is helpfull for the diagnosis of affected area as a method of diagnosis of otolithic function.

7) Some cases showed abnormality in neurological findings, vertebral angiography and electroencephalography. This fact shows that some cases of sudden loss of cochleo-vestibular function have central, especially brainstem lesion.

From the results above mentioned it can be concluded that the genesis and the affected area of these disease were various, and we could locate the affected area in the labyrinth and centrum more fully by not only the hearing tests, but also by varius vestibular function tests and vertebral angiography, electroencephalography etc, as the case may be.

And furthermore it was indicated that some cases, in this disease, having their genesis in the lesion of the central nervous system, 


\title{
末梢迷路疾患に関する臨床的研究
}

\author{
前庭機能を中心にみた突発性聴平衡覚障害の臨床的研究
}

東京大学医学部耳鬼咽㘈科教室（主任：切替一郎教授）

大学院学生 野 末李道彦

\section{はじめに}

とくに原因と思われるものなく急激渂度の神経難聴 が発来するいわゆる突発性難聴に関してはすでに古くか ら多くの報告がある。我々も先年眼振を中必沈突発 性難聴の病像について報告し1，その後聴力型について 2) 又最近では㥁覚々前庭機能の関連から突発性難聴の病 変部位について 推定した。このような今日までの諸 家の報告あるいは我々の報告で扱われたいわゆる突発性 難聴は聴覚だけが障害されたもの又はこれに前庭症状を 伴つたものを対象としたものであつた，一方我々は東大 病院耳鼻咽啒科のメマイ平衡障害外来を訪れる患者を詳 細に検討した結果, メーエール病, 聴神経腫瘍等明らか そその診断名のつけられる疾患は別としてメマイ平衡障 害を訴える患者はその症状から大きくわけて突発性聴平 衡覚障害及び反復性聴平燠覚障害の 2 群があり更にこれ をその障害部位により蝸牛障害型，前庭障害型，混合型 (蝸牛・前庭障害型) および 中枢障害型と分類して扱ら のがより適当であると考学る。例えば聴力障害がなくた だ一回の発作で急激济高度の前庭障害が発来する急性前 庭障害例があり，その原因，病態などから考えてこの疾 腎を従来のいわゆる突発性難聴と切離して別に取扱らこ とは無意味であると思う．従つて私は今回このように急 激㳙庭障害のみあらわれる症例も含めて従来のいわい る㔖発性難聴と共に突発性恥平衡覚障害として一括して 扱らことにした。そして我タのメマイ・平衔障害外来を 訪れたこれら症例につき詳細なる前庭機能検查を行ない その経過を追求し興味ある所見を得たのでここと報告し 御批判を仰ざたいと思ら。

\section{検査対象}

昭和 36 年 1 月上り昭和 39 年 5 月 31 日までに東大㖞 院耳鼻咽喉科のメマイ平衡障害外来を訪れた 164 例の突 発性聴平衡覚障害の患者の中で諸種の事情がら比較的詳 紐に前庭譏能検查を行ない得た 113 例を対象とした。こ れらは全例とる何等原因と思われるるのるなく，ただ 回の発作で急激に神経難聴をきたし又同時にメマイを伴
らかあるいは難㯖はなく、ただ1回の発作で急激な前庭 障慧をきたした症例である。

\section{検查方法ならびに検查成績}

\section{1 素因ならび誘因}

詳細なる問診とアンケートにより集計した。. 表1にみ る如く冷え症・のぼせ症等の血管運動障害があると思わ れるもの39例 (35\%) ですつとす多く次でしんましん， 湿廖のできやすいわのあるいはぜんそくのあるむのな ぞ何等かのフレルギー体質を持つているもの 26 例 (23 $\%$ ，頭痛肩こりを訴えるもの23例（20\%）であつた。 低血圧は，村上・上田 ${ }^{4)} 5$ の分類儿従い $110 \mathrm{~mm}$ 水銀 柱以下とした結果 21 例（19\%）飞認められた．この表 の項目の中で突発性平衡覚障害の原因となり得る音響外 傷, 頭部外傷, ストレプトマイシン, カナマイシン使用 はこれらが今回の発作の直接の原因ではなく既往歷とし て認められたものである. 以前とメマイ発作・失神発作 のあつたものも7例みられるがこれもやはり既往歴とし て認められたものである. 全く素因の認められないもの は26例であつた。

誘因としては特に考えられるものなしと答えたもの

\begin{tabular}{|c|c|}
\hline 困 & 症例数 \\
\hline 冷え 症・のぼせ症 & 39 例 \\
\hline アレルギ一紫因 & $26 "$ \\
\hline 頭痛・局こり & $23 "$ \\
\hline 低 血 正 & $21 \%$ \\
\hline 音＼cjkstart塁 外 & $15 "$ \\
\hline 頭 部 外傷 & $15 "$ \\
\hline 乘 物酥 & $14 \%$ \\
\hline $\mathrm{SM} \cdot \mathrm{KM}$ 使 用 & $9 "$ \\
\hline 高血亚 & $7 "$ \\
\hline 昡弱失神発作の既往 & $7 \%$ \\
\hline 焦 点 感 染 & $6 "$ \\
\hline * & $26 "$ \\
\hline
\end{tabular}


表 2

\begin{tabular}{|c|c|c|}
\hline 誘 & 困 & 症例数 \\
\hline 疲 & 学 & 30 例 \\
\hline 脈 & 邪 & $13 "$ \\
\hline 月経子 & るもの & $9 "$ \\
\hline 拔苗後 & 治療中 & $4 "$ \\
\hline パーー & † 一 後 & $3 "$ \\
\hline ts & L & $52 "$ \\
\hline
\end{tabular}

52 例 $(46 \%)$ であり疲労していたと答えたもの30 例 (27 \%)，風邪をひいていたと答えたるの13例（12\%）であ った，その他月経と何等かの関保があると推定されるむ $の^{9}$ 例，拔歯直後又は虫菌治㙩中 4 例，パーマドライヤ 一をかけ大後，何時間か経過して発作を起したもの3例 となつている。この結果を表 2 に示した，素因ならびに 誘因は夫々重複して訴兄られた項目があるが詳細な問韶 の結果素因ならびに誘因とも全くないものは11 例（10 \%)にすぎなからた。

\section{』聴力 型}

純音間值検査にて行なつたオージオグラムの聴力型を 梌討した．聴力型の分類については諸管によりいるいる

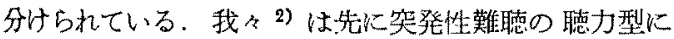
ついて検討しその大部分は高音部障害型，全域障害型に 分けられることを報告した．今回も同じ分類に従いこれ に急激に前庭障害のみをきたした聴力正常のものを加之 た，その結果情了の如く高音障害型 40 例 $(35 \%)$ ，全 城碚害型 60 例 $(53 \%)$ ，正常 13 例 (12\%) であつた。

\begin{tabular}{|c|c|c|c|}
\hline 澺 & 力 & 型 & 定例数 \\
\hline 高 音 & 筷 & 害 型 & 40 例 \\
\hline 全 域 & 障 & 害 型 & $60 \%$ \\
\hline 正 & & 常 & $13 "$ \\
\hline 合 & & 計 & $113 \%$ \\
\hline
\end{tabular}

四眼振

眼振怡查法は切替・坂田 ${ }^{5)}$ 5) 0 自発眼振および誘発

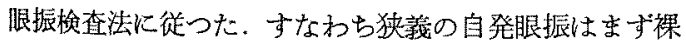
腿で患者に正面涼方視させて検查し，次で注視眼振は左 右上下を約 $30^{\circ}$ 注視させた位䁚で観察した。これらは又 フレンツエル眼鏡装用下にても行なつた。頍位眼振はフ レンンェル 眼鏡装用下まず坐位にて 検查を行ない正面
遠方視させさらに頭部をゆつくり右下・左下・上下に約 45ํ傾けた位置で観察した。次で患者を仰卧位とし何卧 位正面遠方視㧍よび頭部を左右にゆっくりと回旋させた 位圈にて行ないさらに照垂頭位にても同様のことを行な つた，頭位変換検查はやはりフレンッェル眼鏡装用下い わゆる Stenger 法报よび Dix-Hallpike 法について行 なつた．何等かの形で眼振の認められたものは全例 113 例中 91 例 $(80 \%)$ であつた。眼振の認められたものに つき分類してみると狭義の自発眼振のみられたもの 22 例, 注視眼振の認めら机た6の35例, 嗢位眼振の認め られたもの 53 例, 頭位変煥眼振の認められたもの59 例 であつた。この関係は表4に示す如くである。

\begin{tabular}{|c|c|c|c|c|}
\hline \multicolumn{2}{|c|}{ 眼 } & \multicolumn{2}{|c|}{ 振 } & 柾例数 \\
\hline 自 & 発 & 眼 & 振 & 22例 \\
\hline 洁 & 視 & 服 & 振 & $35 "$ \\
\hline 頭 & 位 & 腿 & 振 & 53 \\
\hline 頭 & 1 変 & 亚 & 振 & $59 \%$ \\
\hline
\end{tabular}

眼摭の方向について 检討してみると力向一定性眼振 53 例，万向交代性上向性眼振 11 例， 万方向交代性下向性 眼振 5 例であつた。この方向交代性眼振はフレンッェル 眼鏡を装用して坐位仰卧位执よび思番頭位にて頭位眼振 を検查した場合右下頭位にて左向眼振を，左下頭位にて 右向眼振を示与ものを方向交代性上向性と呼び，右下頭 位にて在向眼振を，左下頭位にて左向眼振を示守のを 方向交代性下向性と呼九た。，又眼振方向と聴力型の関俰 を検討してみると方向一定性眼振は全域障害型に多くみ られる傾向がある，聴力障害のない、急性前庭障害例は

表 5

\begin{tabular}{|c|c|c|c|c|}
\hline 腿振方向 & & 恥力 型 & 症例数 & 合 計 \\
\hline \multirow{2}{*}{\multicolumn{2}{|c|}{ 方 向一定 性 }} & 全域障害型 & $\begin{array}{l}15 \text { 例 } \\
26 "\end{array}$ & \multirow[t]{2}{*}{53 例 } \\
\hline & & 正常 & $12 "$ & \\
\hline \multirow{6}{*}{ 方向交代性 } & 上 & \multirow{2}{*}{$\begin{array}{l}\text { 高音障䨋型 } \\
\text { 全域障害型 }\end{array}$} & 8例 & \\
\hline & 向 & & $3 "$ & 11 例 \\
\hline & & 正 & 0 & \\
\hline & 下 & 高音障害型 & 2例 & \\
\hline & 向 & 全域障害型 & $3 "$ & 5 例 \\
\hline & 性 & 正 & 0 & \\
\hline
\end{tabular}


13 例中 12 例が方向一定性眼振であつた。，方向交代性上 向性眼振は高音障害型にやや多くみられた。これら眼振 方向と聴力型の関係注表 5 亿示した。

次に眼振の打ち万について検討してみると表6に示寸 如〈水平性腿振は39 例で方り水平回旋湜合性眼振は 24 例, 回旋性眼振は 8 例, 垂直性眼振は 18 例であった。 又聴力型との関係についてみると水平性腿振，水平回旋 混合性眼振扣上び回旅性眼振，ともに全域障害型にやや 多い傾问がみられる。垂直性眼振と聴力型の関係には特 に有意の所見を認めていない，聴力正常で急性前庭障害 をきたした症例は 13 例中 11 例が水平性眼振を示した。

\begin{tabular}{|c|c|c|c|}
\hline 恨振の打ら方 & 聴 力 型 & 症例数 & 合 \\
\hline 水平性 眼 振 & $\begin{array}{l}\text { 高音障害型 } \\
\text { 全域障害型 } \\
\text { 正 常 }\end{array}$ & $\begin{array}{l}11 \text { 例 } \\
17 " \\
11 \%\end{array}$ & 39例 \\
\hline 水平回旔混合性腿振 & $\begin{array}{l}\text { 高音障害型 } \\
\text { 全域陴害型 } \\
\text { 正 常 }\end{array}$ & $\begin{array}{c}9 \text { 例 } \\
14 " \\
1 "\end{array}$ & 24例 \\
\hline 回 雄 性 眼 振 & $\begin{array}{l}\text { 高音障害型 } \\
\text { 全域障害型 } \\
\text { 正 常 }\end{array}$ & $\begin{array}{l}2 \text { 例 } \\
6 " \\
0\end{array}$ & 8例 \\
\hline 金 直 性 眼 振 & $\begin{array}{l}\text { 高音障害型 } \\
\text { 全域障害型 } \\
\text { 正 常 }\end{array}$ & $\begin{array}{l}8 \text { 例 } \\
9 " \\
1 "\end{array}$ & 18 例 \\
\hline
\end{tabular}

N 温.度刺激検査

温度刺激検查は Fitzgerald \& Hallpike ${ }^{6)}$ の泠温交 互刺激法を採用し刺激条件は猪・早川》招上び Jongkees 8) の $30^{\circ} \mathrm{C} ４ 4^{\circ} \mathrm{C} ， 20 \mathrm{cc}$ 秒間で注入する方法を用 いた．CP 及び DP の判定方法は同じく Hallpike の 万法に従つた，検查は 104 例について行ない.CP を示 すもの， $\mathrm{CP}+\mathrm{DP}$ を示すもの，正常反心を示するのに 分けた。 この場合温度検查正常とは $\mathrm{CP}$ すなわち水平 半規管機能低下のないものを対象とした，検查結果は表 7 に示寸通りである。

すなわち $\mathrm{CP}$ を示したものは74 例 (71\%)，CP+DP を示したもの8 例 $(8 \%)$ ，正常区応を示したもの22 例 (21\%)であつた，又聴力型との閂係では全域障害型に $\mathrm{CP}$ を示すものが多く, 聴力正常で急性前庭障害をきた したものは全例ともCP を示した。

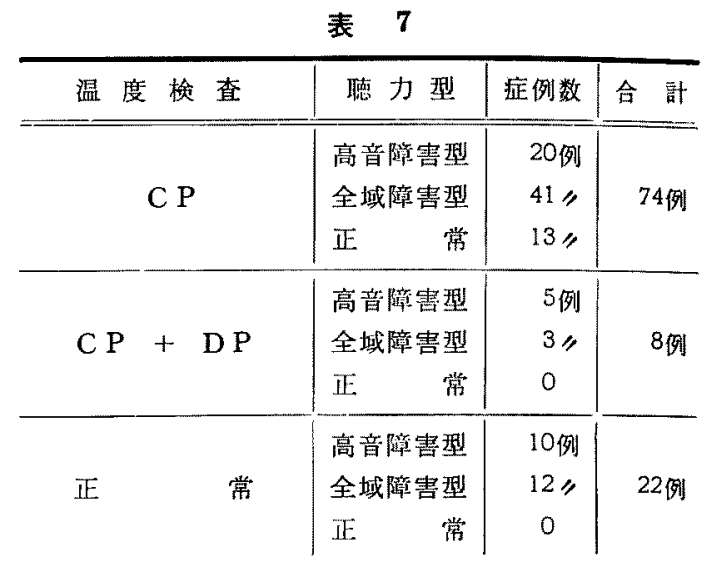

V 視性運動性眼振, Optokinetic nystagmus, (OKN)

電動式回転円筒と艺の回転により解発された眼振を記 録する電気眼振計，Elektronystagmographie (ENG) を用いた。電動式回転円筒は直径 $1.8 \mathrm{~m}$ 高さ $1 \mathrm{~m}$ で内 側は純白でそこに幅 $3 \mathrm{~cm}$ の黒色テープが等間瀜に 12 本はりつけてある。

検査法は鈴木 9１0）５の方法に従い，患者を回転円䈏の 中心にある椅子に腰かけさせ回転円筒を $4^{\circ} / \mathrm{sec}^{2}$ の等㑇 加速度で $0^{\circ} \sim 160^{\circ} / \mathrm{sec}$ まで回転速度をあげその後同栐 な負の角加速度で減速させて $\% / \mathrm{sec}$ とする. ENGの 紙的くり速度はこの場合 $0.1 \mathrm{~cm} / \mathrm{sec}$ として全体の眼振 反応をPattern としてとらえた，そしてこれを Optokinetic pattern (OKP) と呼び右向きに解発されるの を右 OKP，左向きに解発されるのを左 OKP としてい

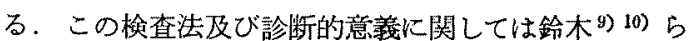
の報告がありなお末梢疾患から中枢疾患に及ぶ詳細な 検討結果については小松㥓 11) 12)13）の報告があるので 参照せられたい，突発性 聴平衡覚障害例 75 例について OKP を検討した結果は表8 亿示す如く末梢型を示した もの59 例 (79\%)，準中枢型を示したもの14 例 (19\%)， 中枢型を示したもの 2 例であつた。

この準中枢型としたのはその Pattern が強い脳幹樟

表 8

\begin{tabular}{ccc|c}
\hline & O K P & 症例数 \\
\hline \hline 末 & 梢 & 型 & 59 例 \\
淮 & 中 枢 & 型 & 14 " \\
中 & 枢 & 型 & $2 \%$
\end{tabular}


書を示すとは考えられないが、そうかと云つて末梢型と す云齐ずどららかと云文ば脳幹障害を念頭に批いて注意 すべきであると考克られるものである。

VI 視性運動性後眼振, Optokinetic after nystagmus (OKAN)

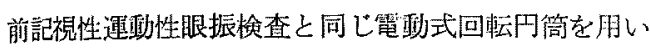
ENG 紙拈くり速度を $0.1 \mathrm{~cm} / \mathrm{sec} て ゙ ~ 1 \% / \mathrm{sec}^{2}$ の等角加 速度で $0^{\circ} \sim 80^{\circ} / \mathrm{sec}$ 又は $0^{\circ} \sim 100^{\circ} \mathrm{sec}$ まで回転速度を あげた後，円筒室内の電気を消して暗室關眼の状態にし ENG 紙括くり速度を $0.5 \mathrm{~cm} / \mathrm{sec}$ にあげて視性連理性 後眼振を記録した。

この結果恃表 9 に示す如く检查 45 例中 OKAN に左 右差を認めたものは35例 (78\%) であり左右差の認め られないるの6 例又左右差もなく且つ OKAN が非常に 出現しにくいもの 4 例であつた.

\section{表 9}

\begin{tabular}{|c|c|c|c|}
\hline \multicolumn{3}{|c|}{ OKAN } & 症例数 \\
\hline 左 & 右 & $(t)$ & 35 例 \\
\hline 左 & 右 & $(-)$ & $6 "$ \\
\hline 出 & $k$ & $<\quad w$ & $4 "$ \\
\hline
\end{tabular}

\section{VII 回転検查}

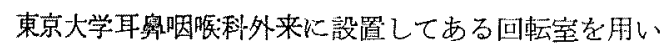
た，被搝者を回転室の中央の椅子に坐ら飞頭部を前屈 $30^{\circ}$ の位置炕固定する．眼振のもつとも出易い暗空開眼 （实際には光の逘蔽を完全にするために暗室遮眼）の状 態にして正面を見させた．刺激方法は德增 ${ }^{1115)}$ 15行な つた方法により $3 \% / \mathrm{sec}^{2}$ の等角加速度で $10 \% / \mathrm{sec}$ の等 速回転から $60 \% \mathrm{sec}$ 芯で回転をはや內 $60 \% / \mathrm{sec}$ の等速 回転汇移りその時の回転恻眼振を ENG で記録し，縄 いて $60 \%$ sec の等速回転から急停止して回枟後眼振を 同様に ENGに記䩮した，そして回忶中及び回忶得眼 振共火その左右差つ有無につき梌討した，表10 に示す 如く挨查 58 例中左右差を認めたものは48例 $(80 \%)$ で あり右回転，左回転共爻回転中，回転後共炏全く眼振の 解発が悪く，両側の反应が低下していると考觉られるも

表 10

\begin{tabular}{cc|c}
\hline 回 枟 娭 & 查 & 症例数 \\
\hline \hline 左 右 差 $(+)$ & 46 例 \\
两例反応低下 & $12 \%$
\end{tabular}

の12 例であり全例とも何等かの罢常所見を示した。

VIII眼球代䁲性反対回烣, Kompensatorische Gegenrollung der Augen (Gegenrollung)

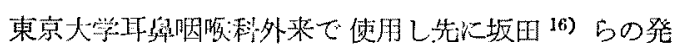

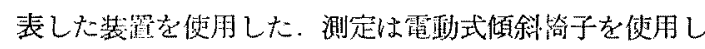
患者をこの焀子に坐ら也頭部，腰部，大腿部をバンドで

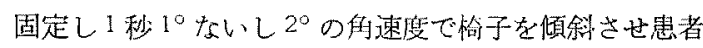
の頭部と頸部を一緒に傾けるようにした，検查は左右へ の傾涂について行ない，便宜上健側腿を閉眼し患側眼に十 字の記号をつけたユデ卯の邲膜を貼付して視覚をとり除 々上共作眼球代償性反対回旋 (Gegenrollung) 認知の

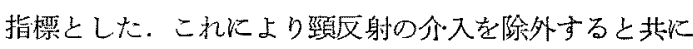
視覚々加速度回莿刺激の湿入支排除して 䇣張性迷路反 射を選択的に検査しうるように努めた。汗うの目標は Vorübergehende Gegenrollung に招いた，寻初患側に ついて行ない次で健㑬につてて行なつた。る 上5な梌 值法に上る場合嚾かな Gegenrollung は見与：場合む あり双反面 Gegenrollung が全く消失してい、㕣むあ り得るので Gegenrollung が出ないかあるいは 跨 りしない場合は $0^{\circ}$ たは不明とした。この検査は、眼振 が著明に出現している場合恃険查不可能であるため 33 例についてのみ行なつた．その結果は表11に示す如く 患側で低下しているものは16 例で約半数を占めこれに 0又は不明のものを加えると全例とも患側で異常所見を

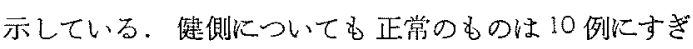
ず健側毛何等か心異常所見を示す症例が多い，又聴力型 との関係では特に有昰の所見は認めら机なかつた。

表 11

\begin{tabular}{|c|c|c|c|}
\hline 峎球代䇛性反刘回旋 & 㯖力 型 & 定例数 & 台 計 \\
\hline 慧＼cjkstart側＼cjkstart低 & 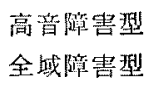 & $\begin{array}{l}8 \text { 例 } \\
8 \%\end{array}$ & 16 例 \\
\hline 㭧侧 ○メ心不明 & $\begin{array}{l}\text { 高音障蔀型 } \\
\text { 全牫瑺㕩型 }\end{array}$ & $\begin{array}{r}6 \% \\
11 \%\end{array}$ & $17 "$ \\
\hline ～側＼cjkstart低 & $\begin{array}{l}\text { 高暗做害型 } \\
\text { 全域障害型 }\end{array}$ & $\begin{array}{l}8 \% \\
5 \%\end{array}$ & $13 \%$ \\
\hline 健僛 ○又は不明 & $\begin{array}{l}\text { 高音噪害型 } \\
\text { 全域厥羖型 }\end{array}$ & $\begin{array}{l}2 \% \\
8 \%\end{array}$ & $10 \%$ \\
\hline 帅 正 & 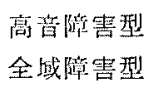 & $\begin{array}{l}4 " 1 \\
6 "\end{array}$ & $10 \%$ \\
\hline
\end{tabular}


X 神経学似検查执よびその他の平衡機能検査

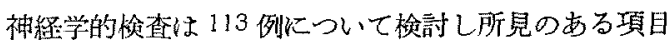
のみを記した，即ら角膜反射の低下しているもの15例 でもつとも多く次で味覚障害 7 例となつている，その他

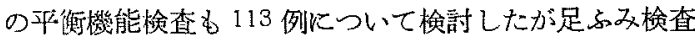

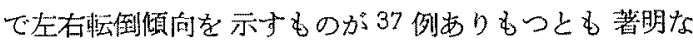
所見であつた，1例ではあるがロンベルグ陽性のものが みられた。この検查結果恔 12 に示した。

表 12

\begin{tabular}{|c|c|}
\hline 媨神経学的检査所見 & 证例数 \\
\hline 角 膜 反射 低 F & 15 例 \\
\hline 味 覚 陪 害 & $7 \geqslant$ \\
\hline 瀩 通 知 覚 低下 & $2 "$ \\
\hline 吅品监 射 低下 & $1 "$ \\
\hline 班 碳 機 能 & 症例数 \\
\hline 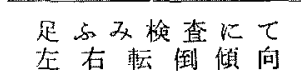 & 37 例 \\
\hline ロンヘンルグ陽性 & $1 \%$ \\
\hline
\end{tabular}

\section{興味ある症例の検討}

\section{I 原因の確定又は推定できたもの}

一般にいわゆる突発性難聴とは乞の定義として何等原 因と思われる機転の不明のまま突然神経難聴をきたした むのとざれて括りその意味では原因の確定できたもの又 は推定されるすのは除外するのが常識のようである，従 つて我宛のこの項目の3 例及び次項目の原因文は動機の 比較的明暌である 2 例は全定例 113 例の中には入つてい ないしししながらこのように突発的に聴平衡覚障害を きたしたすのの病態生理を考える上に原因の明らかな症 例あるいは比較的動機の明らかな症例の検討は欠くこと のできない重要性をるつものと考える。

1. 症例 $56-64$, 宁 26 才

主訴：両側難㯖，雨側耳鳴，左顔面神維麻渒，步行 障害.

現病厢：７年前より多少左難悖に気付くよらになり 次第に腎化するようであつた。1 年前石側の難聴が突発 的に発現したが当時メマイは全くなかつた，その2カ月 後左顔面神経麻症が起り次で 5 力月後左顔面知筧鈍麻に 気付いた。約 10 力月後頃より步行障害を感し約 1 年後 䁩下障害が加わるよらになつた。

既往歴：特記す攵べき所見なし。

图 1 (拼例56-64)

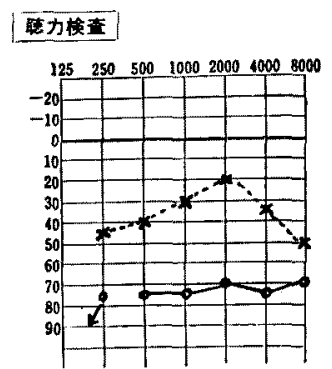

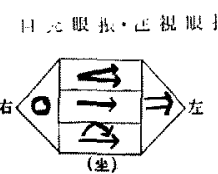

is 位运 战
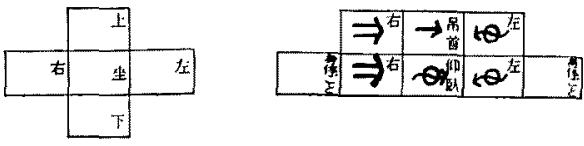

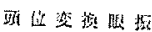
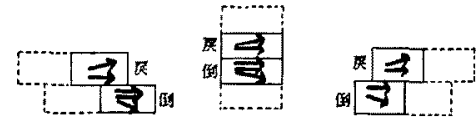

德力は突発的に発症した右侧の障害が高度であ り，眼振は左注視で左に向ら大打性の眼振が， 頭位変換检査ではやや左斜上又は下に向う傾向 がみられる。

检查所見：聴力，自発眼振は図1飞，ENGに上る 自発眼振及び OKP は図 2 に示す

温度刺激検查はアルコールによる簡易刺激検查を行な つたが右眼振反応（十）であるがその反応は極めて弱く メマイ感はない，左眼振反応（一）である．水水でも同 様な所見であつた。

神経学的所見：左角膜反射低下，左味覚障害，左顔 面神経麻疩, 左顔面知覚異常.

その他の平衡機能険查： ロンペルグ陽性，歩ふみ检 查で左右転倒攧向強い

小括：眼振は左注視及び 右下頭位，頭位変換榆查で 左側に向う大打性の眼振を認め頭位変換検查では更に左 斜め上又は下に向う傾向を有し中枢障輩を゙疑わしめ又

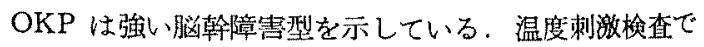
あ左眼振及仙全くなく右眼振反応山認められるか弱 いしかも定状は進行性である，以上の所見及び神維学

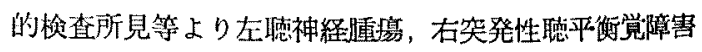


図 2 (症例56-64)
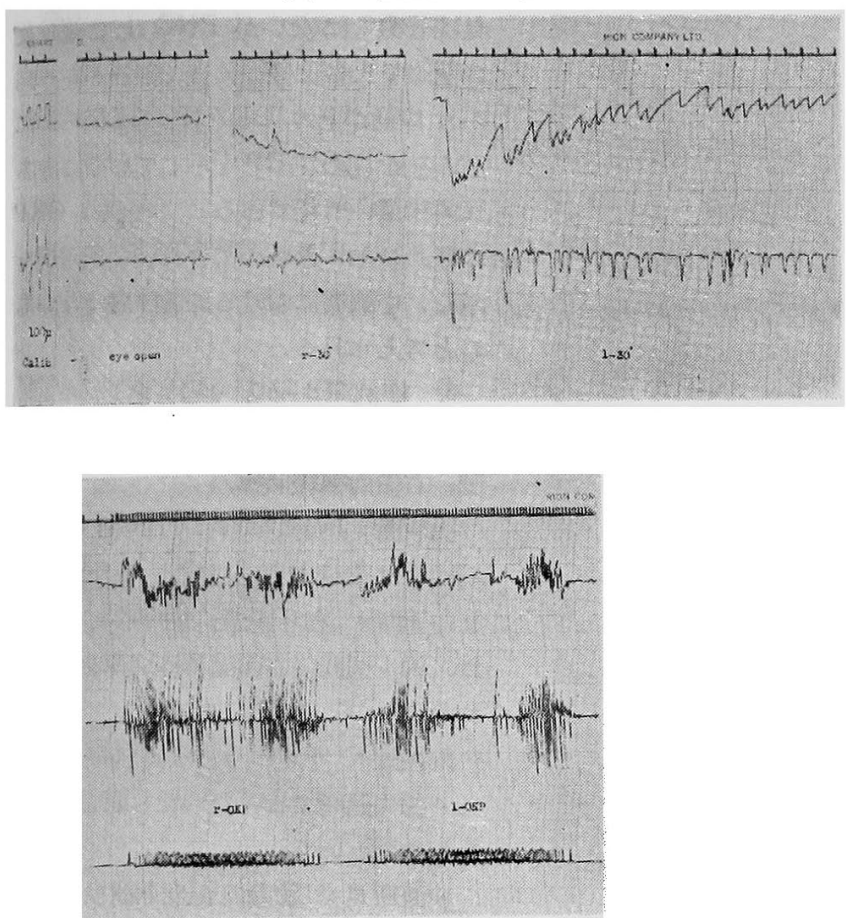

上は自発ならびに注視眼振の ENG 所見で左 $30^{\circ}$ 注 視で大打性の左向眼振がみられる。下は OKP 所 見で強い脳幹障害型を示す

の䛦断の下に開頭手術を行なつ所，左側に鷄卵大の腫瘍 があり右側にる小指頭大の聴神経腫塲が発見された興味 深い症例である. 即ちこの症例は両側の聴神経䏦痬であ り片側俚進行性に又他側は突発性に聴平衡覚障害をきた したすのである.なお Recklinghausen としての゙症状 及び所見は他に認められなかつた。我々はもら1例はぼ 同样な症例即ち 1 側江聴神経腫瘍があり他側に突発性聴 平衡覚障害をきたしたものを経験しておりこのようなこ とはこの疾患の病態及び原因を考察する上に興味深い。

2. 症例 255-64，合 42 才

主訴：頭痛, 左耳鳴, 左難聴.

現病歴：朝起床時起き上万らとして項部に 異常感を 感した．その直後急に意識混濁に陌り以後 3 日間意識朦

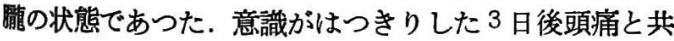
に左耳鳴り，左難聴に気付いた。メマイはフラフラ感を 軽度に感じた程度である。

既往歴：5～6 年前, 肋膜炎に罹患しストレプトマイ シン約 50 本使用したことがある．その他には特記すべ
きものなし.

検査所見: 純音闒値聴力, 眼振, 温 度検查所見は図 3 に, ENG 所見は図 4 に, OKP 及び OKAN 所見は夫々図 5, 図6に示す 聴力は自記オージオで 左側が $1000 \mathrm{cps}$ で TTS 陽性, 左明嘹 度検査は $80 \mathrm{~dB}$ で $40 \%$ ，方向感 ${ }^{17)}$ は $7 \mathrm{~cm}$ であつた。

脳脊髄夜は血性で初圧 $190 \mathrm{~mm}$ 水柱, $5 \mathrm{cc}$ 採取後終圧 $160 \mathrm{~mm}$ 水柱であつた.

神経学的検査所見: 左視力障害, 軽 度言語障害を認める他は特記すべきもの はない。

小括：脳脊随液の所見から，〈も膜 下出血の診断にて内科で治療中であるが この疾患に突発性聴平衡覚障害を伴つた 例として興味深い，聴力は純音間值障害 が軽度であるに拘らず難聴感が強く，自 記オージオ明瞭度検查, 方向感検査 ${ }^{17}$ ) にて後迷路性難聴の要素と思われるもの 多く注目すべき所見である。

図 3 (症例255-64)
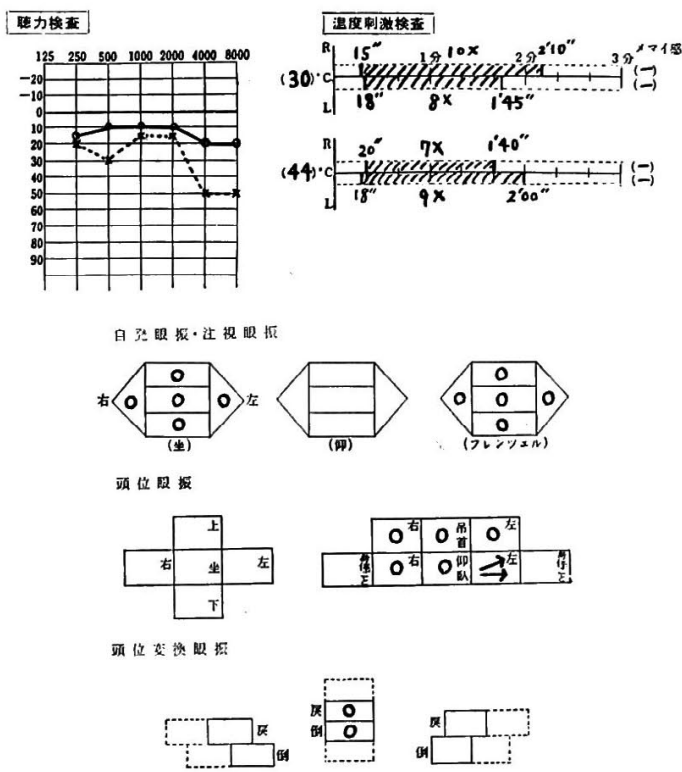

聴力は純音閾値上左軽度難聴を示し, 温度檢查 は左 DP を示し，限振は，左下頭位にて应向 眼振を怪度に認めるのみである， 
図 4 (症例 255-64)

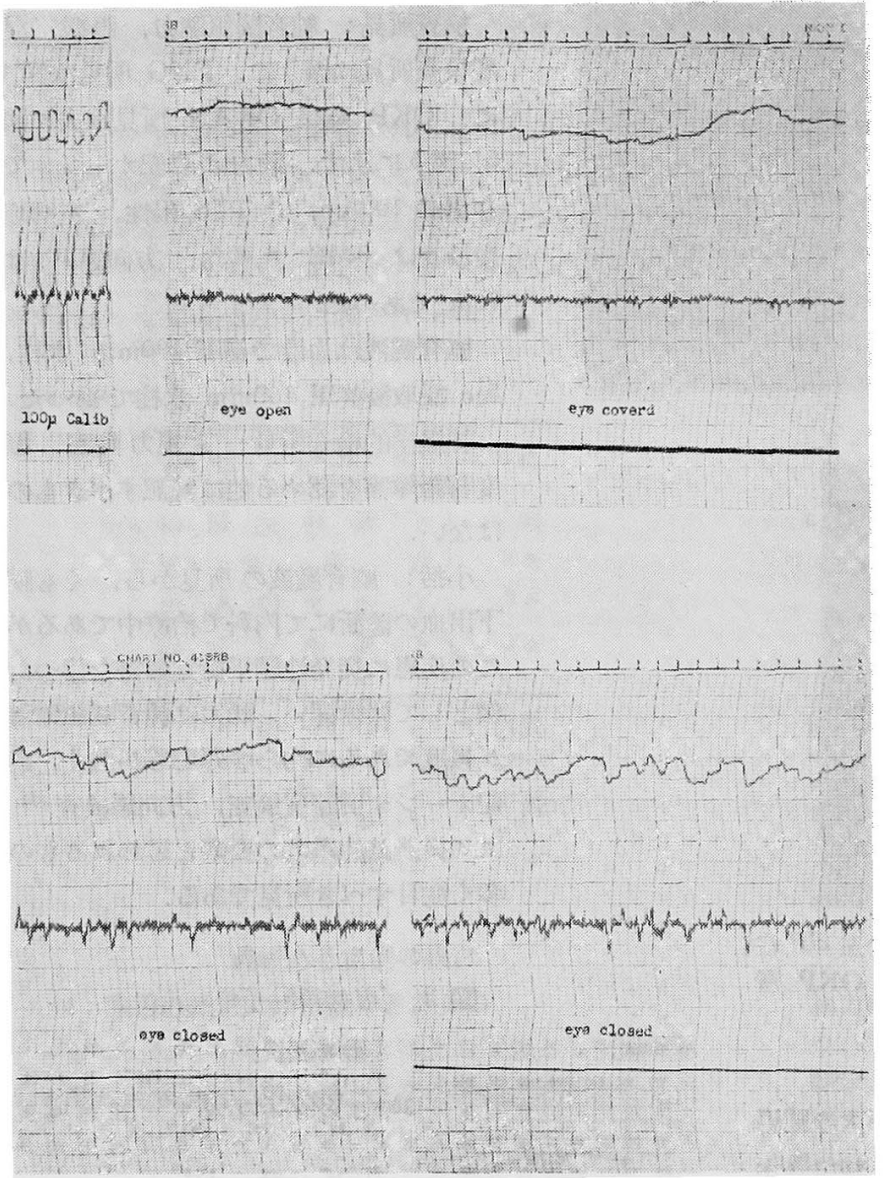

開眼, 閉眼, 遮眼における ENG 所見で, はつきりしたもの ではないが特に閉眼で左向眼振があるようである。

図 5(症例 255-64)

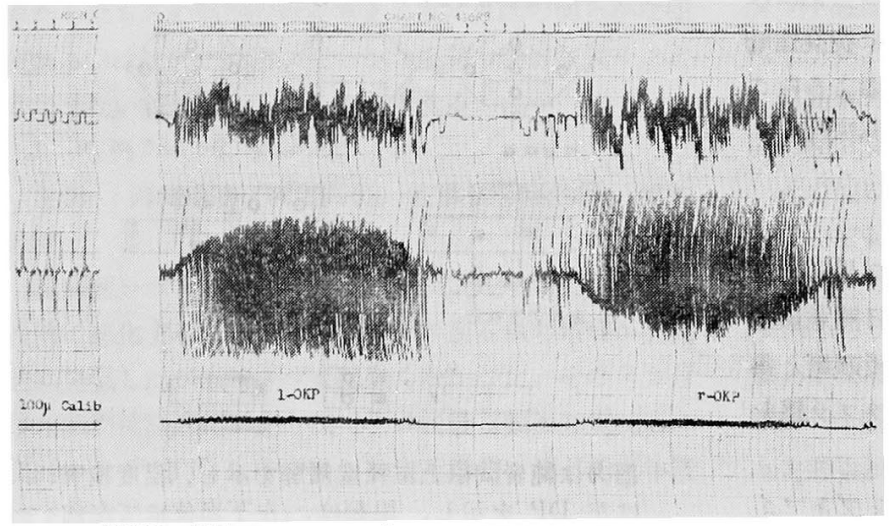

OKP 所見図であるが著明な脳翰倩害は誓められない，
温度検查は左 DP 傾向を示し 眼振所 見は著明ではないが ENG 上で遮眼及 び閉眼で文頭立腿振検查で眼振が左へ向 かう傾向があり OKAN では明らかに 左右差を認め左 DP を示していることも 又興味深い所見である．この例は OKP け図 5 の如くきわめてきれいな正常型を 示し, 中脳橋に括ける脳幹障害はないむ のと考えられる。

3. 症例 258一60, 11 才

主訴：回転性メマイ 右耳鳴, 右難 聴, 右顔湎神経麻瘏.

現病歴：昭和 35 年 11 月 6 日突然回 転性メマイが起り，悪心，嘔吐を伴つ た。同時に右耳閉感, 右耳嘅気付い た. 約 1 週間後右顔面神経麻瘦を指摘さ れた。

既往歴：4才の時左顔面 神経麻㾴が あり約 1 週間でよくなつた. 聴力は悪く なかつたといら。

検查所見: 聴力, 温度刺激検査, 眼 振は図 7 に示す通りである。下の聴力 図は1カ月後の回復した所見である. OKP は末梢型であつた.

神経学的検查所見. 右角膜反射低下. 右味覚障害, 右顔面神絟麻疾.

小括：初診時の 多彩な所見からあ又 第 1 症例の如く聴神経腫瘍で突発性聴平. 衡覚障害をきたす例もあるのでこの症例 も恥神経腫瘍を全く否定することはでき ない.しかし一般的にこのよらな形でく る聴神経蕾厡は少ないこと，温度刺激㭘 查の反応が CP とは云え比較的よく残 つていること，眼振がどちらかと云えば 末梢疾患に多い形を示すこと，又 OKP が未䊑型を示すことなどから多発性脳神 経炎がもつとも考光られるすのとして治 療経過を観察していた所, 症状は次第に 軽快乙聴力, 顔面神経麻痻も次第に回復 し，1 月後には完全に正常になつたと 云う興味深い症例である.その経過から 考学て原因はともかく多発性脳神経炎の 部分現象として突発性聴平北信覚障害を伴 

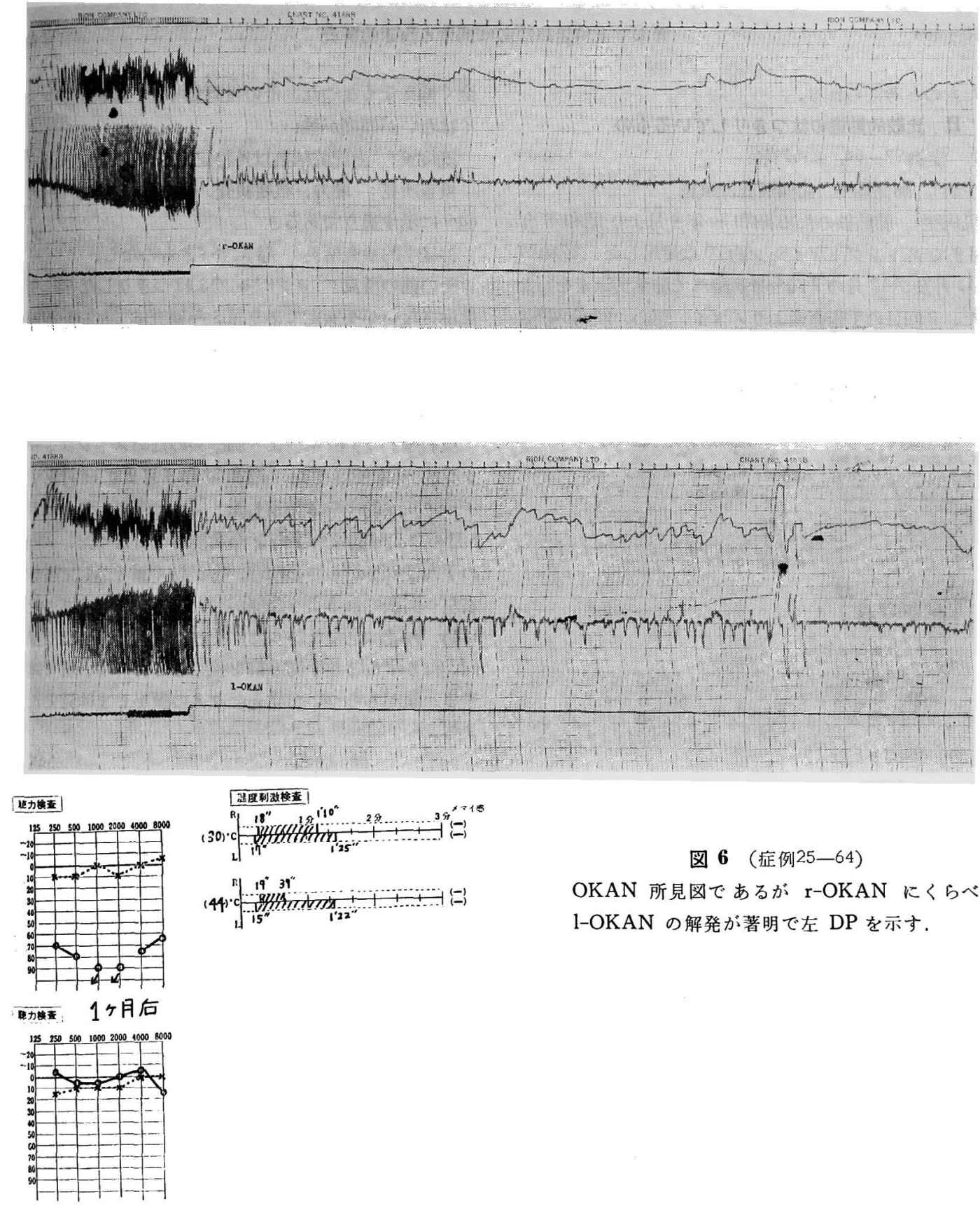

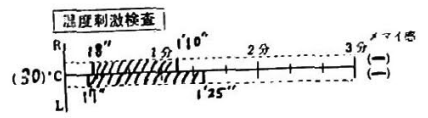

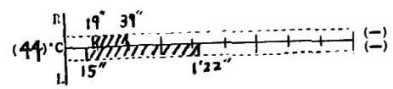

図 6 (症例25-64)

OKAN 所見図であるが r-OKAN にくらべ 1-OKAN の解発が著明で左 DPを示す.

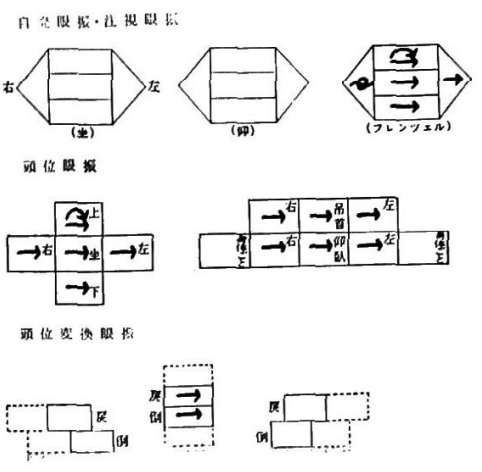

图 7 (在例 258-60)

上の聴力図は発症時のもので 右高度障害を示 し，温度検査は右 $\mathrm{CP}$ を示す，眼振は左に向与 方向一定性, 水平回旋混合性限振を示す下の 聴力図は 1 カ月後の回復した所見である. 
つたものと考えられる。

\section{II 比較的動機のはつきリしているもの}

1. 症例 97-64， 。 57 才

主訴：両側耳鳴, 両側難聴, 頭痛

現病歴：肺結核のため昭和 36 年 4 月上り昭和 37 年 8 月までストレプトマイシン約 70 本使用した。昭和 37 年 11 月及び 12 月の 2 回全身麻醣にて肺葉切除術を行な つた． 2 回目の手術直後よりメマイ 悪心，頭痛が続き 起きられなかつた，手術 1 週間後突然両側耳閉感があり

図 8 (症例97-64)
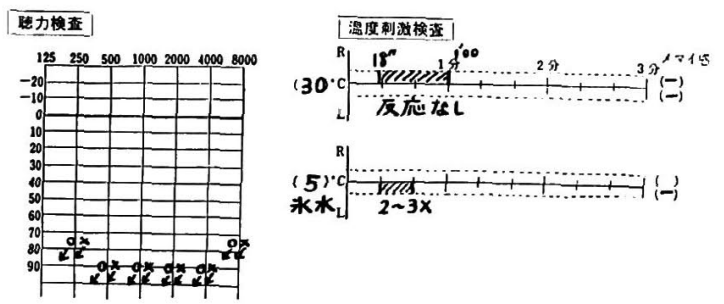

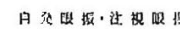
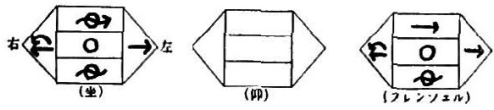

可位眼握
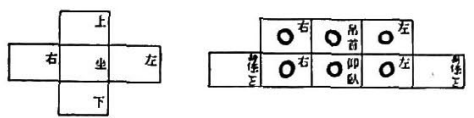

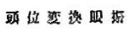

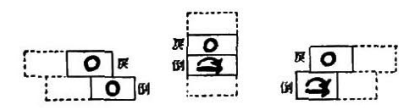

聴力は両側とも全㜪, 温度検査では両側の $\mathrm{CP}$ を示 す。眼振は左右注視眼振が認められる。

図 9 （症例97-64）

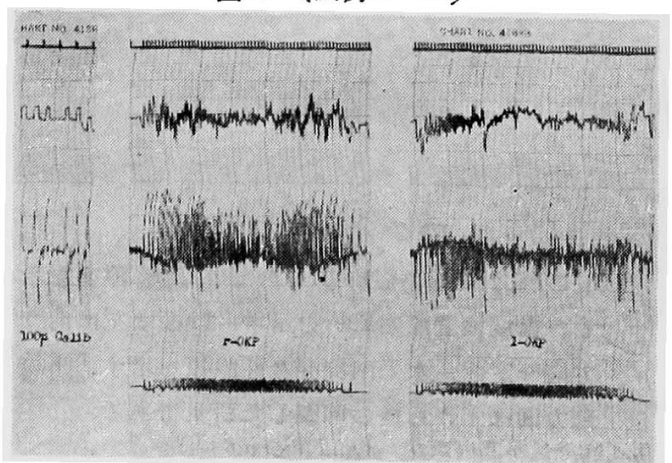

OKP 所見図で眼振解発が悪くきれいな末梢型を示 きず準中枢型を示す
全く聞えなくなつた．その後両側耳鳴，難聴が続きメマ イはないが頭痛が強い.

既往歴：上記肺結核以外特記すべきものはない，

検査所見：聴力, 温度検査, 眼振は図8 8 亿, OKP は 図9に示す通りである。

神経学的検查所見：特記すべきものなし．

その他の所見：ロンペルグははつきりした陽性所見 を示さないが不安定であり足らみ検査にて左右転倒傾向 が強い，

2. 症例 118-63, 8 60 才 主訴：平衡障害.

現病歴：約 10 年前より肺結核のためストレブトマイ シン約 60 本使用 した。昭和 37 年 4 月より 11 月までカ ナマイシン約 100 本使用した。 その間昭和 37 年 5 月と 6 月の 2 回肺結核の手術を 全身麻醉で行なつた。 2 回目 の手術後麻酔からさめた時, 物が動く感じがして眼球か 右左へ引張られるような気がした. 当時悪心はあつたが 耳鳴，難㯖は全くなかつた。それ以来立ち上つたり横を 向いたりするとき平衡障害を強く感じ特に暗い所で增強 する．星がちらついて見えたり人の顔がしまに見えたり する.

图 10（症例 118-63)
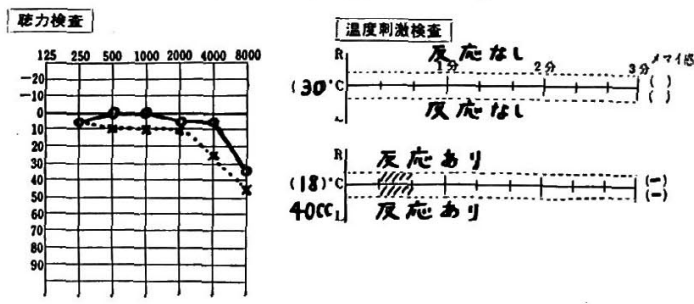

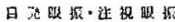
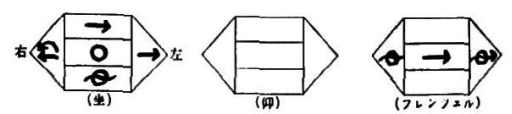

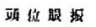
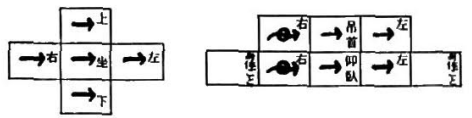

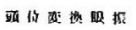

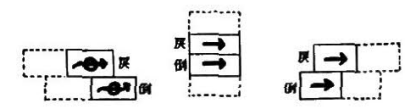

聴力は両側軽度高音部障害があるのみだが温度検查 で両側とも高度 CP を示す 眼振は左右注視眼振 が認められる。 
既往歴：28才の時口蓋破裂手術, 約 10 年前胃潰瘍 の手術.

㭘査所見: 聴力, 温度 刺激検査, 眼振は図 10 亿示 す.

OKP はきれいな Pattern ではないが末梢型であつた。 神経学的検査所見：特記すべきものなし.

その他の所見：ロンベルグ現象は認められないが足 的㭘査で左右転倒傾向が函めて強い.

小括：以上 2 例は共に肺結核がありストレプトマイ シン, カナマイシン等を使用している上に全身麻酔によ る手術直後より発症しておりしかも症例 97-64 は聴覚 々前庭系の両者に症例 118一63 は前庭系のみに障害がき ており興味深い症例之考光られる。

症例 97-64 は聴力は全く脿であり 温度検査で 両側水 平半規管機能低下が著明である. 症例 118一63 は聴力が ほぼ正常であるにも拘らず温度検査による左右水平半規 管㙨能低下が著しい. 眼振所見で特徽的なことは両者と む裸眼にて左右注視性の眼振が認められることである. これは度々のべるごとく末梢迷路の障害ではみられず中 枢障害の存在を示唆していると考えられる。 又強い左 右転倒傾向も，たとい末梢迷路機能が 両側性に低下し ているためとしてもそれのみでは説明し得 ない. 又症例97-64では OKP す末梢型の Pattern を示さず何等かの脳幹障害の合併を 考学させる. しかしこれは両者とも此較的高 令者であることと特に前者では全整であるた め検査法の説明がよくわからないと云つた事 も考虑に入れる必要があろう. ストレプトマ イシン障害の病変部位については数多くの報 告があり末梢迷路より前庭神経核更には小脳 と広い範围に及ぶがここに示した 2 症例は共 に術前ではそれらの障害が自覚されず全身麻 䣲傜より誘発されたものと考えられ注目すべ きものと思う.

\section{III 原因不明のもの}

我々が臨床的に突発性聴平衡障害として抆 ら症例の 大部分はこの原因不明のものであ る. しかしこれ等の症例も詳細な聴覚および 平衡機能検査を行なつてみるとその障害部位 はいろいろで前庭系が主として障害されたも の，蜩牛系が主として障害されたものあるい 俩者の混合型等がありこれについての一部 は既に Sudden deafness の病変部位の論文
图 11 (症例291-62) 37 年10月6日
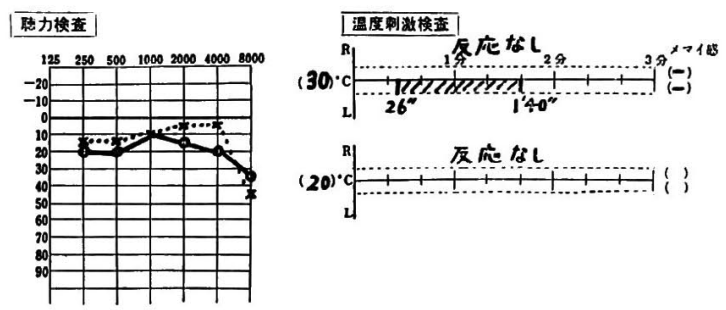

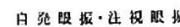
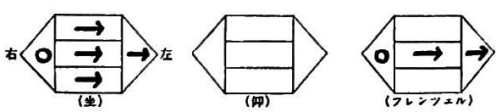

的位眼振
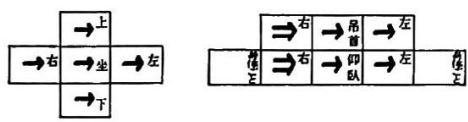

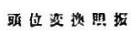

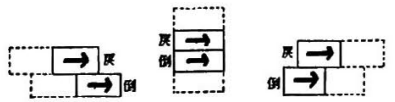

聴力はほぼ正常であるが温度検查で右高度 $\mathrm{CP}$ を 示 す 眼振は左向方向一安性水平性眼振を示す

图 12 (症例291-62)
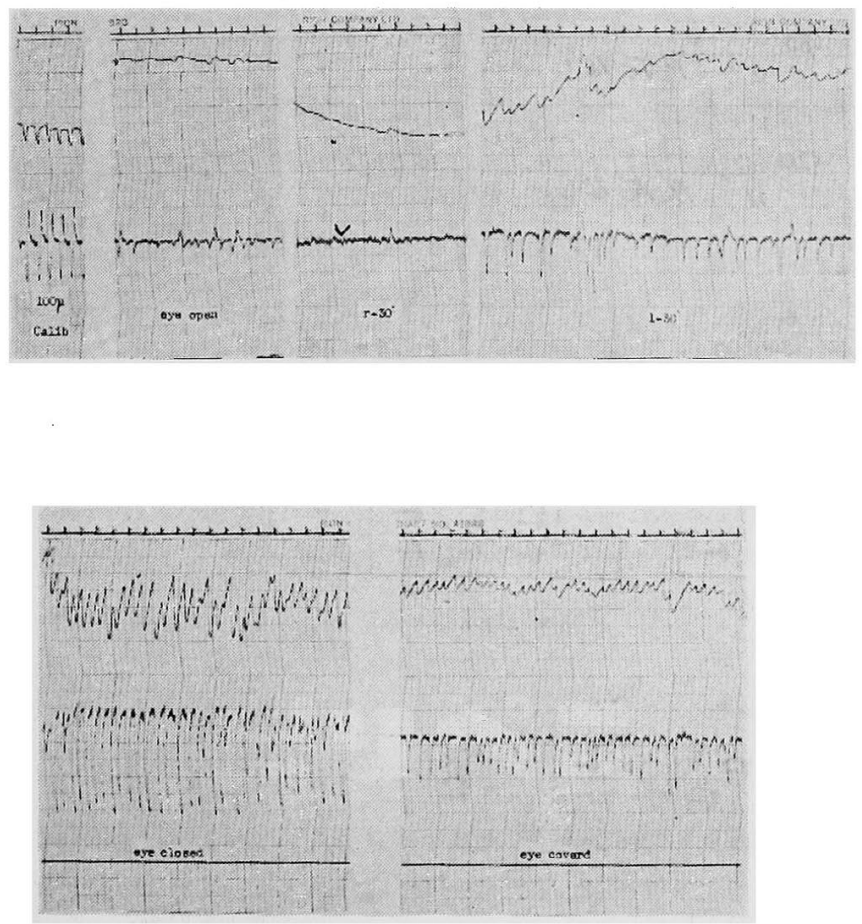

開眼正面遠方視で左向眼振があり, 左 $30^{\circ}$ 注視により増強してい

る. 特に閉眼, 遮眼時の左向眼振解発が著明である. 
3)でふれた．又反面いわゆる突発性難聴は一般に末梢迷 路の疾患と考えられているが詳細に検討してみると末梢 迷路だけの障害とは考えにくく何等かの形で中枢殊に脳 幹障害があるのではないかと考えられる症例がかなり見

図 13 (症例291-62)

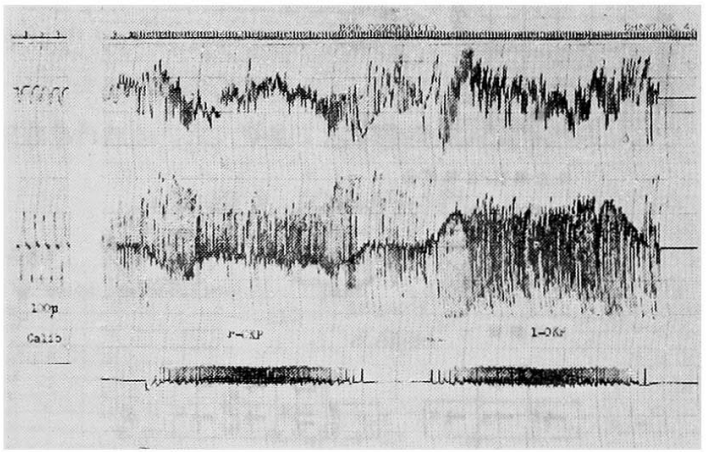

OKP 所見図であるが左向自発胙振があるためOKP は左右差を示し，左向に解発されやすいししかし Pattern は未梢型である.

図 14 (症例 291-62)
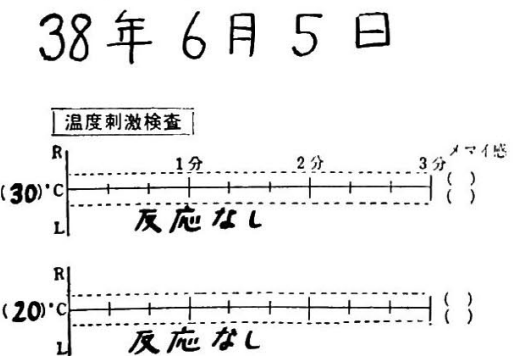

自発眼报・注視眼振
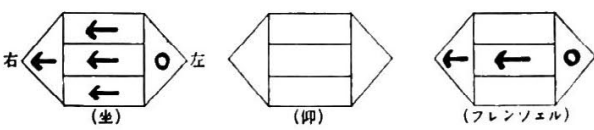

歌位眼提
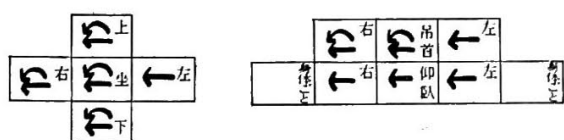

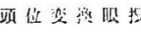

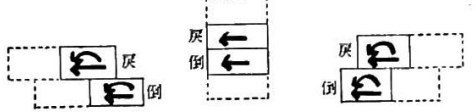

反対侧の良耳に再び発症した時の所見で， 温度検查で左高度 CP を示し，限振は右向 に迎枟している。
られる。このような観点から原因不明のものを検討して みた。

1. 症例 $291-62$, 今 46 才

主訴：メマイ

現病歴：昭和 37 年 9 月 30 日午前，仕事中急に回転 性矓最発作があり 悪心嘔吐を伴つた 同じ日に 2〜3 回軽

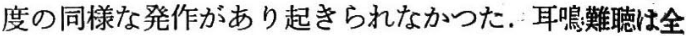
くなかつた.

既往歴：旋盤工のため相当な 騷音の中で働いてお゙り 音響外傷があると考党られる，アレルギー体質，のぼせ 症があるほか 眼科にて 動脈硬化症と云われたことがあ る.

検査所見：聴力, 温度刺激検査, 眼振は図 11 亿, 眼 振の ENG 記録及び OKP は夫々図 12, 図 13 に示寸.

神絽:学的検査所見：特記すべきものなし。

その他の所見. 足ふみ検查にて左右転倒傾向が強い. この症例は経過観察のため外来通院中であつたが炤和 38 年 6 月に再び上記同様のメマイ発作を起した. その 時の 温度刺激検查・眼振所見は図 14 に， ENG 所見は

図 15 (症例291-62)
37。年 12 月 7 日
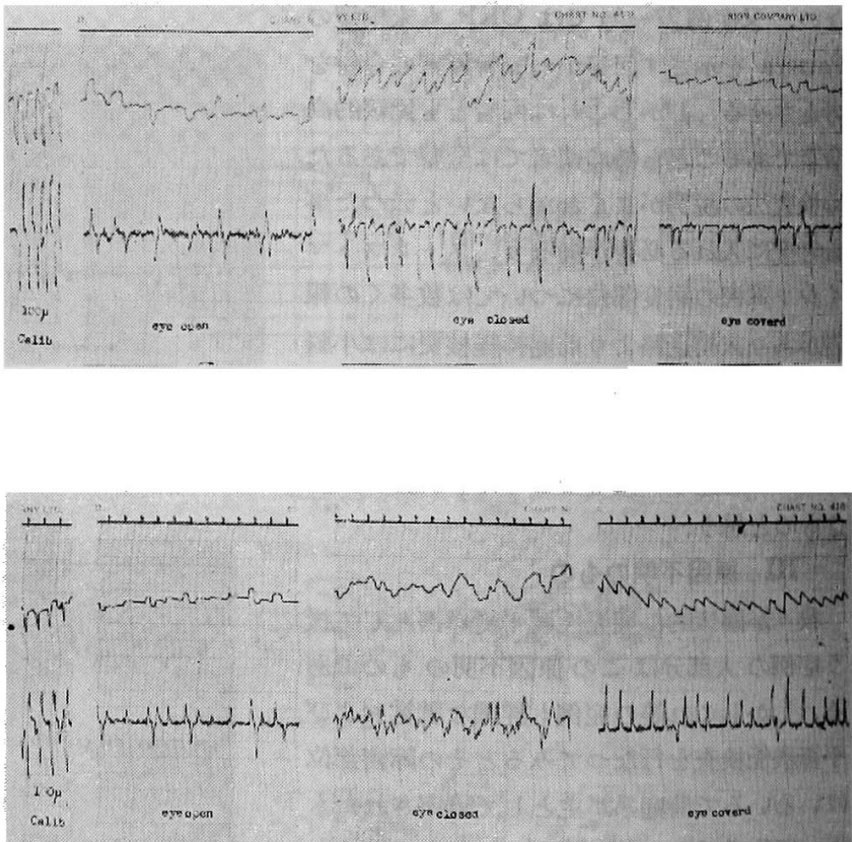

上図は初回発作後の眼振が少なくなつた時の ENG 所見. 下図は 2 回目の発作直後の ENG 所見で眠振方向が逆枟し ている。 
图15に示す，耳鼠・難聴はなく㯖力も前可と全く变り to.

小括：この症例は原因と思われるものなく突然に右 前庭障害をさたし図 15 の上の ENG に示す加く眼振も 次第に少くなり軽快しつつあつたが翌年の6月に再び初 回同様の発作を起し 左急性㓩庭障害を起した6のであ 万.

これが末梢前庭器の 障害であるか Dix-Hallpike ${ }^{18)}$ 等の云う前庭神絟炎であるか断定することはさすすかしい が聴喾系には全く障害がなく温度检查にみる如く高度の 迷路機能低下を示ししかる相次いで反刘側にも全く同様 な障㕩をさたしたことは興宲樑いことである。

眼振は方向一定性で水平回旋混合性であるがこのよう な障韦の場合，同様な眼振所見が認められることが大部 分で，むし前庭神絰炎であるとすれば病变部位診断にと り意義ある所見と云らべきである，OKP は自発眼振の ため左右差が諗められるが Pattern は未梢型であり， 譄神経学的所見むない拘らず歩ふみ検查で左右転倒㑯 向が強いことは注目すべきである。

2. 迹例 $57-63$, 934 才

主挀：右耳鳴，右難聴

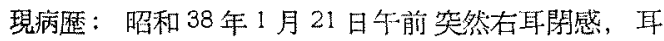

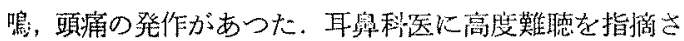
れた、メイはなからたが翌日頭位変換眼振検查中に回

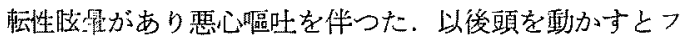
ラフラするメマイが続いた，

既住愿：肺浸㧚と云われ療養したことがあるがスト レプトマイシンは使用しなかつた。

检查所見：㴔力，温度刺激検查，眼振所見任図16k 示す通りである。

OKP は米梢型で左右差名なかつた，眼球代保性区刘 回旋は雨側とも0又は不明であつたが頭部の又傾けた恃 の Gegenrollung は右下 $10^{\circ}$ 左下 $20^{\circ}$ で患側低下齐示 した，神経学的所見及びその他には特記すべき所見いな かかた。

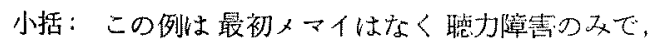

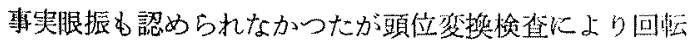
性メマイが誘発されそれ以後は図にみられる姏き純回注 性の眼振が浔められるようになつた舆味深い症例であ

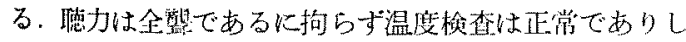
かも Gegenrollung が患側で低下している所見は注日 すべきとである。即ちるし Gegenrollung が正しく 耳石器区射を示しているとするならはここの例水平半規
国 16 (拉例57-63)
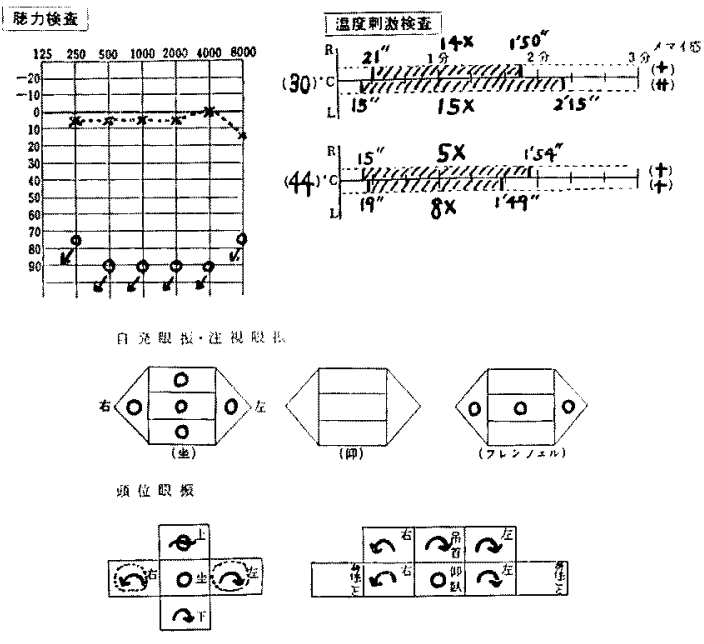

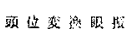

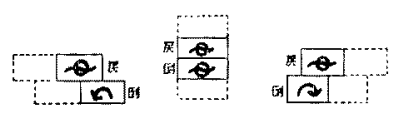

聴力は右全馨であり，温度検查で CP は認められ ず正常反応を示している。哏振は，頍位眼振，頭位 变換眼振检查で純团掟性腿振が諗めら九る。

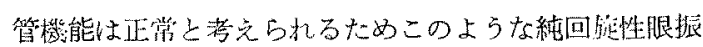

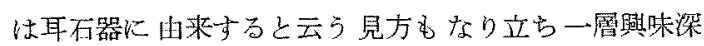

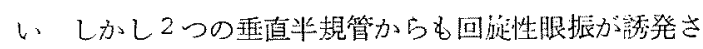
れることがあり又その上 Gegenrollung の信頼度にも 限界があると思われるので上記の如く耳石器障害による ஃマイ又相眼振と镍定することは現在の所困難である。

3. 症例 $211-63$, 卉 31 才

主訴：メマイ 左耳嘭; 左蜼聴

現病歴：䀡和 38 年1月夜中に目がさかた所, 急に左

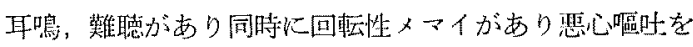
伴つた，2週間は歩行できずねていた。来院持頭を動か したり、ねが竞りをらつとメマイがすると云ら。

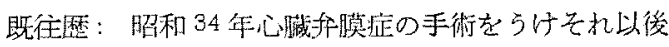
ジギトキシンを服朋している。

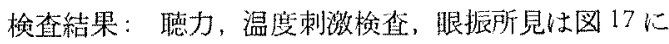
示す通りである。 OKP は末梢型であるが左に出やすく OKAN b左DPを示した，神絽学的所見，その他には 特記すべきのはない。

小括：この症例は温度梌查で全く反応がなく障害の

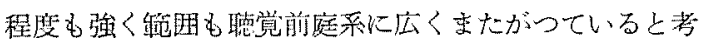

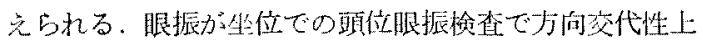


图 17 (症例211-63)
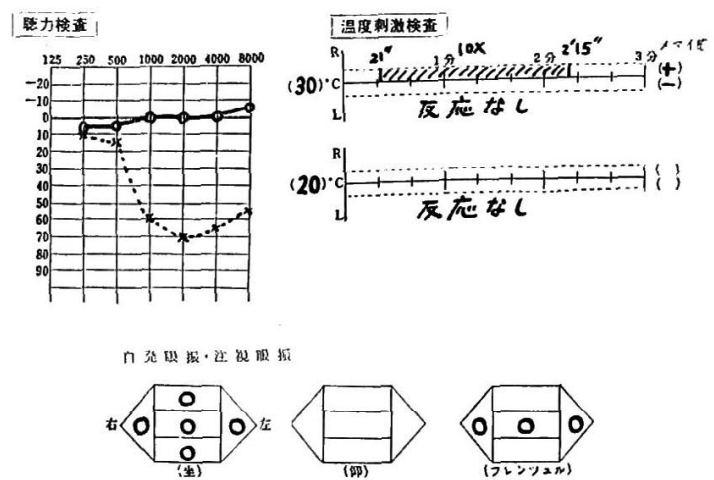

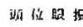
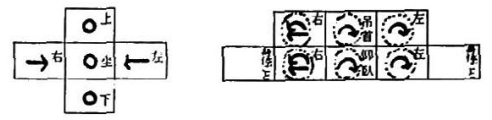

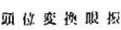

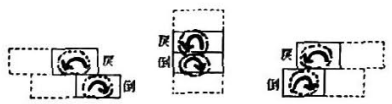

酒少は左高音部障害型を示し, 温度検査で左高度 CP を示す 坐位での頭位眼振では方向交代性上问 性眼振を，仰臥位では回旋性眼振が認められる。

问性を示すに拘らず仰卧位にすると純回旋性となりメマ イ感を訴えることは眼振発現機搆を考方る上で興味深 い.

この症例が頭の位置を変えることによりメマイ感の発 来する傾向が強いためメニエール病あるいは良性発作性 頭位敗最に 効果的な事の多いRosen 氏鼓索神経切断術 を施行してみたが効果はなかつた．この問題に関しては 症例数が少ない上に Rosen 氏鼓索神経切断術の作用機 序も不明の現在断定的なことは云えないが，このような 手術結果からも突発性聴平衡覚障害とメーエール病ある いは良性発作性頭位眩最とは発現機序又は病態が異るの ではないかと推定することは可能であるう。

4. 症例 327-62, 各 45 才

主訴：右耳鳴, 右難聴, メマイ

現病歷：風邪気味であつたが 夜突然に右耳鳴に気们: いた，同じ日の夜中腎心があり目がさめると回転性メー イがあり同㭙に右難聴に気代いた，来院時聴力は多少改 善したようだと云い右下頭位で回転性メマイがあるとの 东である。

既往歴：通信業務に軍隊時代より 現在まで従事して 牤り音響外傷の疑がある以外特記すべきものはない。
図 18 (症例 $327-62$ )
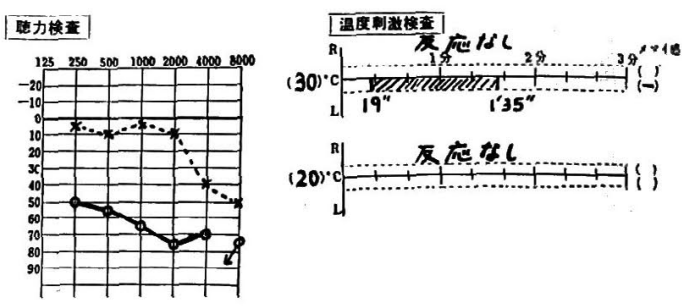

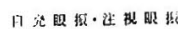
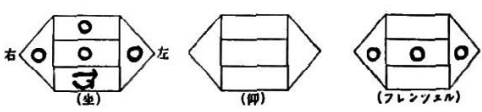

浩位眼报
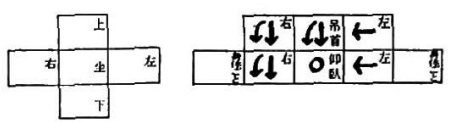

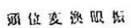

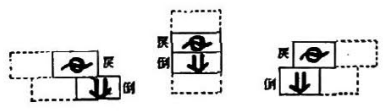

聴力は右全域障害型を, 温度检查では右高度 $\mathrm{CP}$ 示す 頭位哏振で垂直性回旋眼振が頭位变換検查で 倒した時大打性の垂直性眼振が認められる。

図 19 (症例327-62)

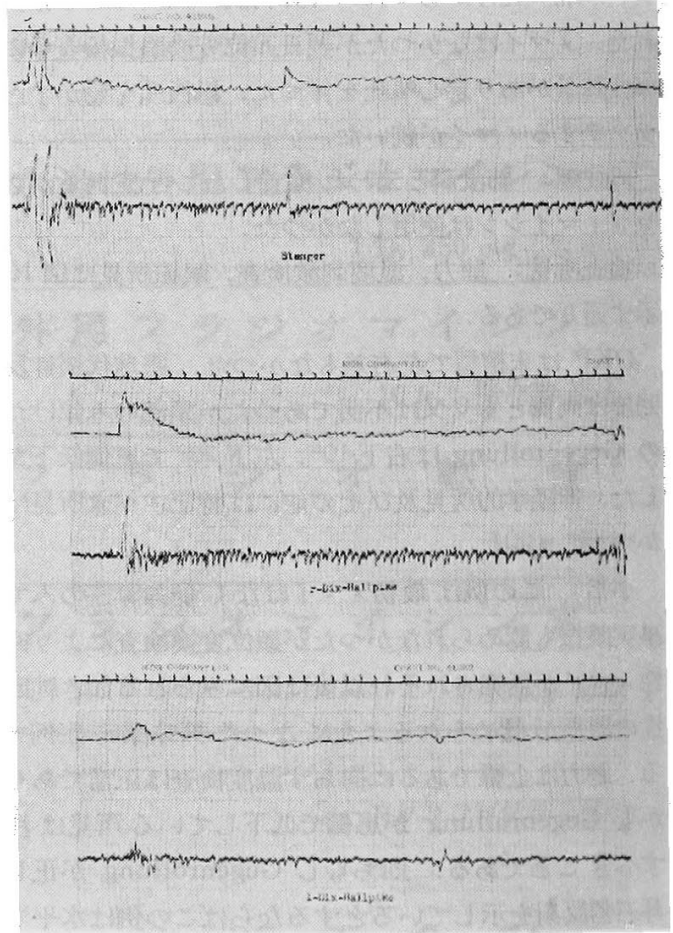

垂直性限振の ENG 記録所見因. 上は Stenger 法, 中・下は Dix-Hallpike 法による。 
検査所見：聴力，温度 刺激検查，眼振 所見は 図 18 に，ENG による 垂直性眼振記録は図 19 に夫々示す OKP は末梢型であつた.

神経学的検査所見：右角膜反射低下，右味覚障害， 右顔面知覚異常.

その他の検查所見：足ふみ検査で左右転倒傾向強く 椎骨動脈撮影で椎骨脳底動脈の triple curvature に異 常が認められ脳波も異常所見を示した．脳室撮影では異 常がなかつた.

小括：この症例は温度検査の 反応低下が高度で眼振 も中枢殊に脳幹障害に多い所見を示し，多彩な神経学的 所見及ぴ平衡障害を認めるため中枢性障害を疑い脳外科 に依頼した所椎骨動脈撮影扰よび脳波に異常所見を認め た.

OKP では著明な脳幹障害を示さず中枢症状と云つて も重篤なものはないため腫嫁等の存在は一応否定すると しても末佾迷路の病変と共に末梢障害を起したと同じ病 変例竞ば血管障害あるいは脳膜癒着等が中枢殊に脳幹に あるのではないかと考えられる注目すべき症例である。

5. 症例 205-63, \% 17 才

主訴：前頭部痛, 右耳鳴, 右難聴, メマイ, 後頭部 の重い感じ.

現病歴：昭和 38 年 2 月朝突然右耳閉感, 右耳鳴に気 付いた．翌早朝目がさめると回転性メマイがあり悪心嘔 吐を伴つた。 4〜5 日は起き上がる事ができなかつた．2 〜3の病院でメニエール病, 脳腫瘍，脳出血等の診断を らけた.

既往歴：頸部結核性淋巴腺炎に 陮患したがストレプ トマイシンの注射をらけたことはない。

検査結果：聴力，眼振所見は図 20 に示した。温度刺 激検查はアルコールで行なつたが両側ともよく反応し た. OKP 所見は図 21 に示寸通り 小脳・脳幹障害型を 示している.

神経学的所見：特記すべきものなし.

その他の検查所見：足ふみ検査にて 左右転倒傾向が 強い，椎骨動脈撮影で閉塞の疑の所見を認める。

小括：この症例の特徵は特異な 眼振所見及び OKP の所見である. 即ちこのような大打性の左右注視眼振は 末梢迷路障害ではまず認められることは全くないと云つ てよく極めて中枢障害の氮いの強い所見である．更に方 向交代性上向性頭位眼振及び大打性の垂直性眼振は注意 すぺき所見である，OKP む小脳・脳幹障害型を示して いることは中枢障害の蛼付けとして 注目すべきであろ 5. 他の所見が比較的少なく眼振及び OKP にのみ中 枢障害を疑わせる所見を認めることは誠に與味深いこと
图 20 (症例205-63)

\section{聴力検查}

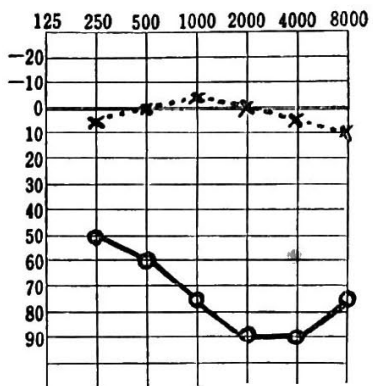

日辇眼振・注祝眼振
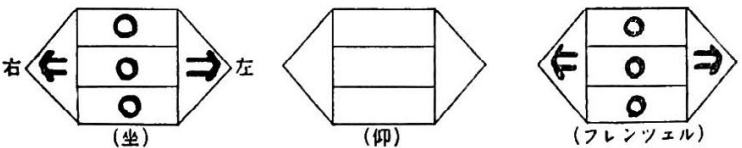

碩 仙 眼 振
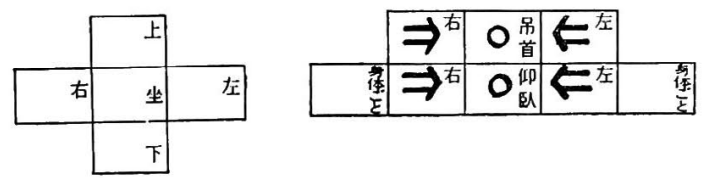

顽位恋衡眼振
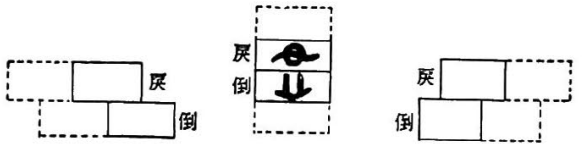

聴力は右全域障害型を示し，眼振所見としては大打 性の左右注視眼振, 方向交代性頭位限振及び重直性 眼振が認められる。

図 21 (症例205-63)

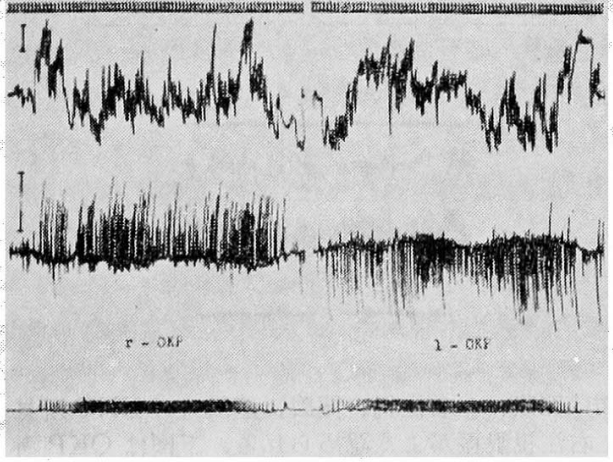

OKP 所見で小脳・脳幹障害型を示す 
と云わざるを得ない，椎骨動脈撮影の所見にも，闒塞が 疑われることはこれ又注目すべきものと思う．

6. 症例 326-63, + 56 才

主訴：回枟性メマイ 左耳鳴, 左難聴.

現病歷：昭和 38 年春頃より右難聴に気付いていた. 左側はよくきこ壳た．同年 9 月頃回転性メマイ発作があ り数時間続いた。聴力は特に変動しはかつた。その後

図 22 (症例326-63)
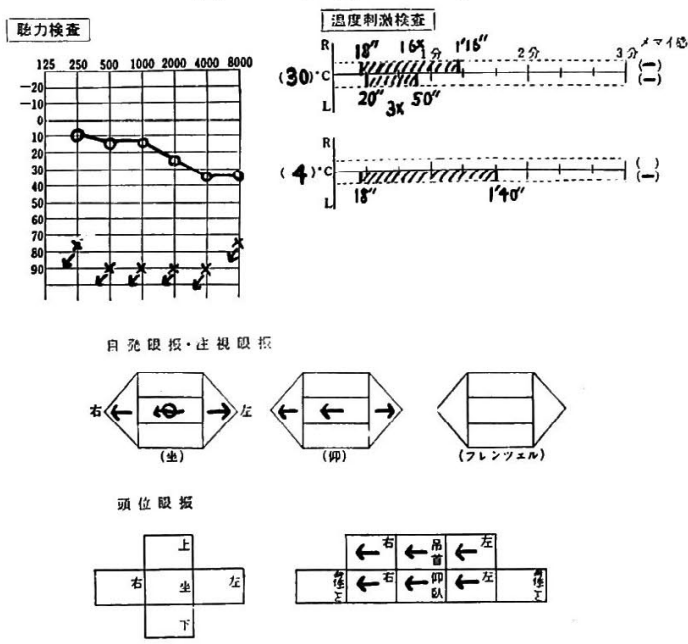

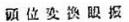

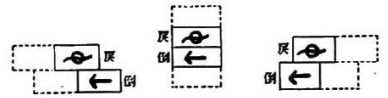

聴力は左全龔であり，温度検查では左 $\mathrm{CP}$ を示す 眼振所見としては左右注視眼振が認められる。

図 23 (症例326-63)

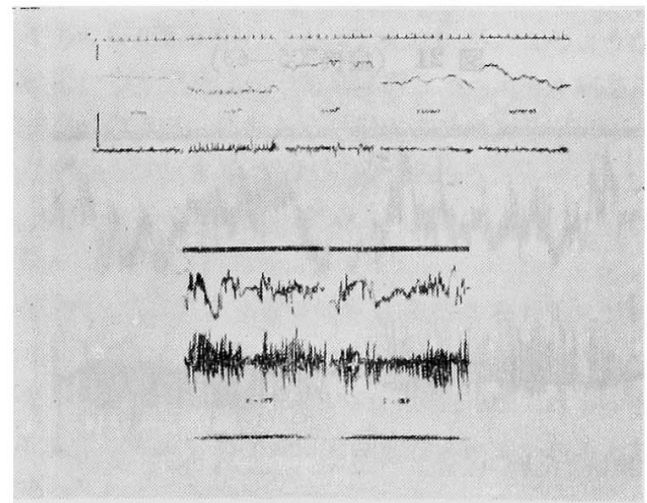

上図は開眼，左右注視，閉眼，遮眼時の ENG 所見 で左右注視限振がくく認められる。下図は OKP 所 見で脳幹障害型を示す，
10月3 日に同様つメマイ発作があつた. 10 月6 日左顔 面のシビレ感があつた．10月9 日突然に 左側難㯖が発 現したがその時メマイはなかつた。

既往歴：特記すべきものなし.

㭘查所見．聴力，温度 刺激検査，眼振所見は図 22 に, OKP 所見は図 23 に示す

神経学的検査所見: 左顔面知覚異常. 左顔面 神経麻 疩の疑いがある。

その他の所見：ロンペルグ陽性，足ふみ検査にて左 右転倒傾向強く殆えど不能である. 左 Disdiadokokinese $(+)$. 眼底㰾脈硬化症の所見がある.

小括：この症例む前症例と同じように左右注視眼振 が認められ OKP は脳幹障害型を示すことが特徵的で ある. 乙か子突発性障害を起寸以前に回転性メマイ発作 を 2 回くりかえしていることも注目すべきことである. 以上の所見及び眼底に動脈硬化症を認めたことから中枢 の血管障害による突発性聴平衡覚障害が考兄られないで あ万らか。内科側の診断によると (1) 急に発作的に起 つている. (2) 前馳症状か゚ある. (3) 発作後軽快して いる.（4）左顔面神絟，第 8 神経に所見があり，小脳脑 幹症状がある．(5) 眼底に動脈硬化症の所見がある，等 の点より脳底動脈の循環不全を疑つている．この症例は 4〜5 カ月後には諸症状が 軽快して扰りこのような場合 いづれにせよ椎骨脳底動脈の病变を疑つて検討すべきも のと考える。

\section{考察}

従来から云われているいわゆる突発性難聴，我々の云 ら突発性聴平“澛覚障害の原因病態については古くから多 くの学者により考察され血管性病変, 神経炎, ビールス 感染，アレルギー性病変あるいは内リンパ水腫等極めて 多様に報告されている。この点に関しての文献的考察は 最近では Ganz ${ }^{19)}$, Bosatra \& Dé Stefani 20), 山崎 ${ }^{21)}$ 等により詳細に報告されているので繰り返すことは避け たい，これら諸家の報告を見てもこの疾患の原因病態に ついては未だ不明の事が多くいずれね仮説の域を脱しな いのが現状ではないかと思う. Schuknecht 22) は4 例 の剖検例について検討しビールス感染による内耳炎にそ の原因を求めようとし特に流行性耳下腺炎あるいはそれ に類似のビールスがこの疾患の原因として重要な要素を 占めるのではないか之推定している. しかしこの報告も 少数例についてでありこの所見をすべての症例にあては めるには無理があり当を得たことではない．勿論ビール 不感染による症例もあるであろうがむしろ我々はこの疾 患の原因を一元的に説明することは無理であり個々の症 例によりいろいろな原因が考えられるのではないかと思 
う、いずれにせよ特にこの疾患が諸家の報告あるいは 我々の報告りにみる如く20才代，30才代に多い事から 考えて，その治療は極めて大切な事であり従つてその原 因についていろいるな立場からの詳細な検討がもつとる 必要な事と考劣る。この上うな意味から患者のむつてい る秦因及び発症当時の誘因について，又症例の検討に扤 いても病变部位の診断と共に原因的考察に重点をおい た. 男女差, 年令差, 患側, 耳鳴・難聴・眩最の前後関 保沉ついて前著でもられ諸家の報告とも大差なく年令 差をのぞいては特に有意の所見を見出しがたいので今回 は省略した。

患者倍細な問診を行なつて，聞き出し得た素因は表 1 亿示す通り冷兄症，のぼせ症あるいは頭痛，局こり等 自律神経障害ひいては血管運動性障害々関係が深いと考 党られるものが多く注目に值する。従来からの諸家の埌 告をみると，諸外国に执いても本邦に执いても一般に血 管性病変にその原因を求める傾向が強く我々のこの所見 るこの考方方を裏付けるるのと云えないであろうか，症 例 255-64 の如く，〈も膜下出血保合併して発症したも の, 症例 205-63 及び症例 327-62 の如く脑幹障害を強 〈疑わ垃る眼振を認める上に，疑程度ではあるが椎骨動 眽血管撮影により異常所見を認めるものあるいは症例 326-63の如く椎骨脳底動脈の循環不全の考学られるる の等が少なからず見られる事は血管性原因説の強い根拠 となるのではなかららか。

最近胘血管障害と頸部動脈病変について注目されれるよ うになつた 23) 24) が突発性聴平衡覚障害も他のメマイ疾 患と共にこの面からの検討がますます必要となるである 5 .

低血圧は 21 例, 高血圧は 7 例にみられるが 全体の数 から考学ると必ずしも有意の所見とは云い難いが血圧は 一般にその变動あるい恤管性病变との関連においては しめて意垡が見出されることが多くこの点の検討も又欠 くことのできないるのである．血王及び血管性障害を問 題と寸る場合全身及び局所の自律神経機能との関連が当 然起つてくるがこれに関してはすでに「末梢迷路疾患の 自律神経機能 25)」でふれた．音響外傷，頭部外傷の既 往歴のあるるのは夫ネ15例となつている。このような 障害が直接の原因となつて発症する場合は対象とならな いが今回の発空とは直接には関係のない既往であるとし てもこれらによりしばしば聴覚前庭機能障害が起ること を考えると等閑視するわけには行かない，即ち音響外傷 あるい顗部外傷により潜在的な内耳の障害が起りそれ
が Locus minoris となり，何等かの誘因により血管性 であ机あるいは他の原因であ机容易に障害を起すである らことは充分考光られる。同様の事はストレプトマイシ ン，カナマイシン使用者についても考克られる所であ る. 症例 97-64 及び症例 118-63 の如く相当大量の ス トレプトアイシン，カナマインンを便用しているに拘ら ず手術前までは自覚的に何等の障害も起して招らず全身 麻醉と云う大きな侵酸が加わつてはじめて発症している 例もあり注目几值する，即ちストレプマイシン，カナ マイシンによる障赛部位は末䊑迷路から前庭核更には小 脳にまで及ぶとされている $\left.{ }^{26)} 27\right)$ がこの障害が潜在的に 存在する所一全身麻酔により例穴ば一過性にあるいは一 部に頚血状態乃至は循環不全をきたし突発性聴平衡覚障 害を起したと考えられぬであろらか。

既往歴に鉬显失神発作を経験した事のあるるのが7例 あつた．突発性聴平衡覚障害例にこのような既往歴をる つものは一般的に少なく症例 326-63 の如く睹最発作に 引続いて突発的に障害を起す例は別としてこの上うな例 はすでにこの発症を起し易い準哄状態にあったことは充 分考えられる所である。

さて誘因はどうであろうか，この疾患の発症原因をつ かもらとしてその誘因についてくわしくしらべてみても まず何の手掛りもつかめないのが大部分である，我々の 检討でも全例 113 例中何等考兄られる誘因なしと答えた ものが 52 例で約半数近くを占めている。．身共に疲労 していたと答えたもの30 例風邪を引いていたと答えた あの13例であつた．乙かしこれも患者の主観的な訴光 でありどの程度信頼性の和ける有意の所見かと云う判定 を下すとなるとその意義つけけはむらかしい，乙かし一般 にメマイ患者はその経過を観察していると心身の疲労と か感冒に罹患することによりその症状が增悪する傾向が 強い，従つてこのような誘因炕より，それが血管性にし 万感染乃至は神経炎にしろ何等かの障害を起し易い状態 になつていたであるらことは推定できる、月経と関保が あると思礼るものは9例であつた。これは月経が極め て不順であるとか月経中に発症したと云う症例である。 月経中とか月経前後は, 全身自律神経状態が極めて不穴 定な時であり田辺28)等の報告によるとこのような时メコ リールテストの反庆型が变化すると云われておりこの疾 腎発症の誘因として考克られ得る根拋があるのではない かと思う．少数例ではあるが抜歯後又心虫雪治療中に発 作を起したものが 4 例，パーマドライヤーをかけた後に 発症したものが3例あることは而白い标である。このよ 


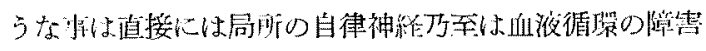
上綝びつけて考它るのがもつとも妥当のようで西るが抜

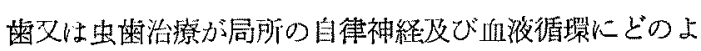
らな影響をあたえるか，又パーマのドライヤーが血液循 環にどのような影響をあたえるかについてその因果関係 は不明であり今後の検剖にあた齐ばならない，しかし又 一方冷房のよくきいた部屋でメニエール病発作を起寸症 例のあることを併せ考党ると注目に值する所見ではなか ろらか。以上のべた如く突発性㯖平衡觉障害の原因はい ろいろ考えられるが見在の所推定的考察の域を脱しきれ ない現状である。 Bosatra \& De' Stefani 20) は原因の 明らかな群と原因不明の碓にわけ，明らかな原因として 梅毒，ビールスによる感染，血管障害，ストレプトマイ シン等の蒋物中毒，蚛神経腫謤等をあげている，我々の 症例をみても聴神経腫瘍に伴つたるの，クモ膜下出血に 伴つたもの，多発性脳神経炎として発症したものあるい はストレプトマイシン中毒に全身麻醉が何等かの影響を あたえたと考えられるものなど多様である。この上うに

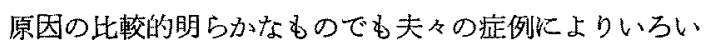
ろな原因に上つて㔖発性聴平衡障害は起り得るものであ る. 從つて原因不明のものについても画一的説明は無理 であり各症例についてるつとす考学られる原因を詳細に 検徍することが必要ではないかと思ら。聴力型は表 $3 の$ 如く, 离音障害型, 全域障害型に分け更に, 聴力障害は なく前庭系にのみ急性障害をきたした例を聴力正常型と して加えた．聴力型をこのよ5に分類することはこの疾 患の病変部位を他の所見上共に検討考察する上で必要な ことである.聴力正常で急性前庭障害のみをきたした症 例方少ないのはやはりこの疾患の性質上聴覚乃至は前庭 系のみが単独で障害されることは少なく、両者になたが つて，いるいる障害される例が多いためと思われる.大 部分は純音闒值检查のみ行なつたが症例 255-64の如く 純染闎值聴力障害が軽度であるに拘らず難㯖感が強く後 迷路性障害が疑的れる例では語音明瞙度検查, 自記才一 ジオメトリー等の精密聴力検査が必要であることは云う まですない。

\section{次に眼振について検討してみよう．}

企例 113 例中何等引の形で眼振を認めたものは91 例 であつた．限振の全く認められなかつた22 例中，班力

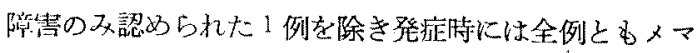
イ発作を伴つている，従つてこれらの症例も発病時には 眼振が出現していたことは考矣られこの点については発 武より米院するまでの期間及び障踳の程度それに詨寸る

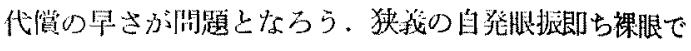
もフレンッェル腿鏡装用下でも正面遠方視ですでに眼振 の誌められたものは22 例であつた。これが比較的少な いのは発症後短時日のうちに大学病院を訪れるものは少 なく大部分発作がかざつてから乃至は何等かの治療を らけて来院するためであるらと思斿れる．注視服振は 35 例に認められるがこの中には左右注視眼振の認めら れるものも含んでいる.この左右注視眼振は, 眼振の発

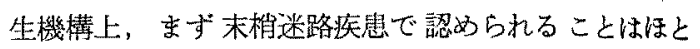
えどなく，中枢殊に脳幹障害に極めて特徵的なもので ある. 症例 97-64, 症例 118-63, 症例 205-63 又症例 326-63の如く左右注視腿振が認められる場合は脑幹障 害を疑うべきであり, 前 2 例の如く脳幹小脑障害の考之 られるものは別としても突発性㥁平衡覚障害例にこのよ らな眼振が認められることは注目すべきである。頭位眼 振，頭位变換眼振の認められたものは头々 53 例，59例 であつた．この中には狭義の自発眼振即ち正面遠方視で 既に眼振の認められるものは入つていない，従つて狭義 の自発眼振が認められなくても頭位眼振, あるいは頭位 変換眼振検查により眼振の認められる率は高く，しかる この所見が診断の有力な一助となることを考点るときこ れ等検査の重要性は今更，㝘をあたない所である。

\section{次に眼振方向ならびにその聴力型との関係についてみ} よう.

表 5 亿見る如く頭位眼振を方向一定性眼振と方向交代 性眼振に大きく分け更に方向交代性眼振は上向性之下向 性に分けた，この眼振の説明は檢査方法ならびに検查結 果の項目で述べた，方向一定性頭位眼振は約半数が全域 障害型にみられ高音障害は15 例にみられた。一航に方 向一定性頭位眼振は末梢迷路疾患儿多く又られるとされ ているが中には聴神経腫湯などのテント下疾患，あるい はテント上疾患でも認められると云われ必ずしも一定し ない，聴力型との関係もここにあらわれた数字から有意 の所見とするのは困難であるが，ただここで注目すべき

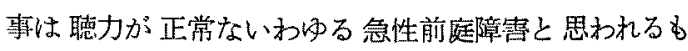
のはその 13 例中 12 例が方向一定性眼振を示しているこ とである. 即ちこの疾患が Dix \& Hallpike ${ }^{18)}$ の云う 前庭神経炎であるとするならば純粹な前庭神経障害の診 断にとつて重要な所見と云わさるを得ない，電気腿振检 查法の診断的意義が末だこんとんとしている現在このよ うな面からの検討る今後必要であろう，万方向交代性頭位 眼振については Nylen ${ }^{29)}$ 等は中枢疾患により多く認め られるとのぺ文坂田 30)等は特に方向交代性上向性頭位 


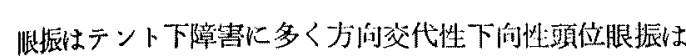
テント上疾患汇認められるとしている，事契，中枢疾患 について恰討してみるとこの傾问が認められ注目すべき 事であり特に症例 205一63 の如く大打性の方向交代性上 向性眼振が見られる場合は脳幹障害の存在を念頭に和い て注意すべきであろう。しかし突発性聴平衡覚障害症例 の方向交代性眼振を経過を追つて観察しているとある洔 は方向一定性になり又ある時は万向交代性となり又上向 性であつたものが下向性になつたりでその力向が变るこ とがしばしばみられまさに眼振は生きていると云ら表現 がよくあてはまる症例が多い 一方 Fernández ${ }^{31)} の$ の猫 による実験，Jongkees ${ }^{32)}$ の鬼による実験又 Jongkees の温度検査後の頭位眼振の検討などは末梢迷路障害でる 方向交代性眼振が出得る根起を示している，従つてある 洔点で方向交代性眼振を認めたとしても直ちに中枢障害 を云々寸ることは早計であり眼振の方向性だけから病変 部位を診断することは現在の所，困難であると云わざる を得ない，又眼振を問題とする場合その振幅の観察が必 要となる. 即ち中枢障害に由来する眼振は大打性であり 小打性のものは末梢迷路障害によることが多い，従つて 方向交代性頭位眼振を論ずる場合もこの面からの検討が 必要であることは云うまでもない：このことに関しても その一部は前著でふれた. 鲵力型との関係についても方 向交代性上向性眼振が高音障害型により多くみられるが これが有意の所見であるかどうかは上に述べたような意 味で軽々しく断定できない，しかしこのような眼振がも しる末梢迷路障害により出現すると仮定するならば耳石 器あるいは垂直半規管はどの程度関与しているかと云う

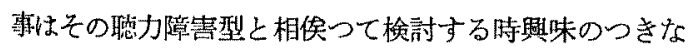
い所である.しかしこれは今後の問題である.いずれに しろあさらかな枢疾恝には方向交代性眼振が認められ ることが多いので，突発性聴平衡覚障害例にもこのよう な眼振を認めた場合は上く注意して充分に他の所見を参 誟しつつ経過老追求すべきであることはいらまでるな W.

\section{眼振の打ち方とその聴力型との関係はどうであろう か.}

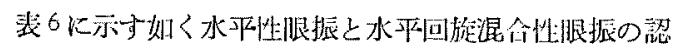

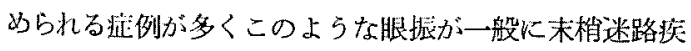
患に認められる事が多いことを考克るとうなずける新見 である、聴力型との関係では必ずしる有意の所見を示し てはいないがここでる注目すべき牙は聴力正常な急性前 庭障害例 13 例中 11 例が水平性眼振を示していることで

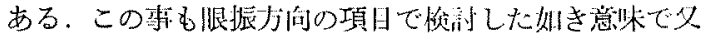
重要な與味方る所見と云わざるを得ない，頭位腿拔倹查 で回旋性眼振は 8 例公られ全域障害型に多く見られる。 回旋性眼振については Ruttin ${ }^{33)}$ は耳石器由来説をと な克坂田 ${ }^{34)}$ 等もほ湆同様な意見である。しかし一方， Flourens は純回旋性眼振は前半規管から出現すると云 い又敛木・Cohen. Bender ${ }^{35)}$ と上ると一側の前後垂直 半規管を同時刺激すると純回旅性眼振が発現することを 猿猫について証明している。我々が猿について前半規管 を破猡した実験でる回旋性垂直性の眼振を認るている。 従つてこの眼振が末梢迷路障害により出現することは異 論がないとしても耳石器あるいは垂直半規管がどの程度 関与しているか断定することは困難である。しかし症例 57一63 の如く聴力は全瑟であり温度刺激による反応が 正常であるに拘らず眼球代償性反対回旋検查で患側の機 能低下が認められる症例で回旋性眼振を認めた事などを 併せ考るると與味深い事である。頭位眼振㶼査及び頭 位変換眼振検查で垂直性眼振は18 例にみられるが聴力 型との関係には特に有意の所見は認められない，垂直 性眼振は一般に中枢疾患に特幑的とされている，一方 Fürstner ${ }^{36)}$ の報告，Fernàndez ${ }^{31)}$ の猫による 实駼は 末梢迷路障書でも垂直性眼振が出得ることを示㖫して掠 り又 Svane-Knudsen ${ }^{37}$ ) 本乫発性難聴例飞これを認め ている. しかし垂直性眼振之思われるものの中には回旋 性要素を含む場合がしばしばあり特に振幅の小さい垂直 性腿振の場合その中に含まれる回施性要素は見逃し易 い.これは鈴木 ${ }^{36)}$ らの猫・猿による一側の前半規管刺 激笑験又 Cohen, 鈴木 ${ }^{38)}$ らの同様な垁験によつても5 かがい知ることができる.従つて Fürstner, Fernández 及び Svane-Knudsen の観察もあるいは回静性要素の 混在を見逃している先㰸性は考学られる。垂直性眼振が 末梢迷路より出現し得ることは又上記の鈴木, Cohen ${ }^{36)}$ 38）5の両側前半規管双は両側後半規管 同時刺激贸験に よつても認められている。このような点を考えると，垂 直性眼振がいが汇中枢障害に特街的々は云えこれが出現 したからとて直ちに中枢疾患と断定することは早計であ

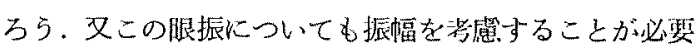

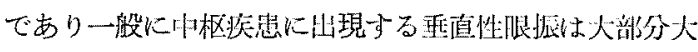
打性である，從つて小打性の垂直性胙振の意我づけに心 米だ䦌題があるとしても症例 327-62, 症例 205-63の 如く中枢疾患にしばしば見られる大打性の重值性腿振を 認める場合は一応中枢殊にテント下障害の存在を念頑に おき他の諸検查を充分に行ない䇺重に注意すべきである 
5. 以上服拔所見を中心にのべたが現在の所，眼振所見

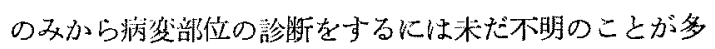
く困蓶である.しかしながら腿振の観祭は耳科神経学们 龍断にとつて，不可欠の梌查でありその所見が䛦断にと つてしばしば有力なより所となる事があり，特に何らか の自発ならびに誘発腿振を証明することはそれのみで前 庭系の異常を知る他覚的所見として重要な意義がある。 從つてこの眼振所見を参考にしつつ充分なる他の検查を 併せ行ない総合的判定を下すべきであることは云うまで もない。

眼捙の項目に関連して次のことを検討してみたい，即 ち，突発性聴平衡覚障害例はメマイ発作をくりかえすこ とはないか.

いわゆる笑発性難聴についてはその定議は発作が 1 回 のみであるとされている、しかし我々が観察した症例の 中には2 3 年の経過を追求する中に短時間の小発作で はあるがメマイ発作を再発したものが 3 例あり上記の今 まで云われていた定義は必ずしも真ならずと云い得る。 再発作に伴つて聴力の変動は全く認めていない，しかし この3 例中 2 例忙 2 年百至 3 年絟過してb腿振の続いて いる例であり何等かの原因でこのような再発が起つても 不思議ではないと思う. 又眼振の出ていない例でも最初 の発泟の動機から考えてほぼ同㥞な動機が加われば再発 作を起すことも又当然と云えよう.症例 291-62 の如く 約数カ月後に再び他側の急性前庭障害をきたした症例も あることはこのような推論の裹付けとならないであろう か.

\section{次に温度検查の結果につき検討してみたい}

梌查104 例中 CP を示したものは74 例 (71\%) であ り，病変の広さを物語るむのと云元よう、聴力型との関 倸では CP を示与もののらち41 例が全域障害型で半数 以上を占めていることは双病变の摭りから考光て当然と

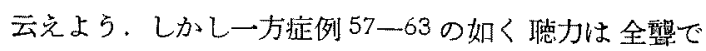
あるに拘らず温度鮧查正消でしか子特徽的な眼振可胃を 示している例もあり注目すべきことである。このような 事からこの温膺㭘查山あくまで水平半規管愉查であるこ とを忘れてはならない，與味深いことは聴力正常で急性 前庭障害のみをきたした 13 例は企例とも CP 所見を示 していることで蝸牛系に全く障製がないに拘らず削庭系

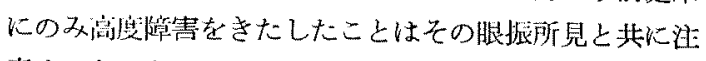
意すべきであろう、又反面聴力障慧があり瞱最発作があ

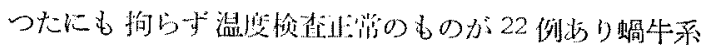
の障害により弼庭系への余波が少なかつたことを物語り
病変の掂りを考祭する上で舆味哚い，CP+DP は耳石 器障害との関連で検討されることが多いが今回の我々の 所見では特に有意の所見を見出し得なかつた. 又 $\mathrm{CP}$ を示すものの中には高度 $\mathrm{CP}$ すなわら水水に刘しても 全く反応しない症例むあり，このことは半規管の高度障 害を示するのであるとしても聴神释腫瘍などでは楩めて 早期に温度検査の反応が低下するとされており注意すべ きであろう，症例 56-64の如く明らかに聴神経腫煌を 認めたものは別としても症例 327-62 の如く高度 CP を示す他, 眼振所見, 神経学的所見その他の所見でも中 枢障害を示寸症例では特に聴神経腫场の有無の判定は必 要であり充分なる検討と共に厳重に経過を峴察すべきる のと思う.

\section{さて視性運動性眼振はどのような所見を示すであろう} か.

視性運動性眼振については Bárány ${ }^{39)}$ 以来多くの学 者により検討されてきた。最近鈴木9310)らは，はじめ て等角加速度による連続刺激を利用して解発された視性 運動性眼振 (OKN) を一つの Pattern としてとらえる ことにより眼振の分類あるいは原因疾患の鑑別が可能で あることを指摘した．この検査法ならびにその後の検討

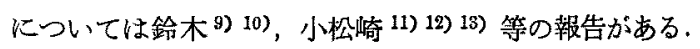
著者孔笑発性聴平衡觉障害 75 例につき検討した絬果を 表8に示した，即ち末梢型を示したものは59 例で大多 数を占めているがこのことはこの疾患の性質上うなつけ る所である. 準中枢型を示したものは14例であつた. 準中枢型の意味は前述したが更に若年者と高令者では OKN の解発に差があり従つて, OKP のP Pattern も高 令者ではきれいな末梢型を示さないことがありこの点で 準中枢型にはな扣検討の余地があるう。しかし症例 97 一64の如くその障害が脳翰にもあるのではないかと推 定される例で準中枢型を示したことは注目すべき所見で はなかららか。 又2〜3 年にわたり方向交代性上向性頭 位眼振が出現している例でもが準中枢型を示すことがあ りそのような時は患者自身具合が悪いと訴克て持り一過 性にしろ例えば血管性障害などが脳幹部に起つたためで はないかと推定され興味深いことである。準中枢型につ いてはなお今後倹討すべき問題が残されており勿論他の 㯺休浙見と共纪総合的判定を下すべきものであることは 云うまでもない，少数例ではあるが中枢型が 2 例みられ た，一般にいわゆる突発性難聴にメマイを伴つたるのは

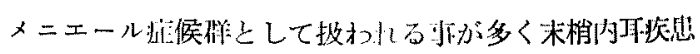
によるものと教えられてきた。しかし De Kleyn 40)の 
如くその特異な眼振所見及び視性眼振の異常から中枢に その病変を求めようとしたものるある。我々もすでに前 著て腿振を中心炕た病態像を検討しこの疾患には脳幹 障害を伴つたものがあることを推論した，従つてこの OKP 所見にも中枢型を示寸症例のあることはこのよう な中枢病变説を 襄付ける 根拠となるであろう．症例 56 一64の如く明らかに 聴神経腫場があり脳幹障害を伴つ ているものは別として症例 205-63 の如く眼振が明らか に中枢障害を思わせる所見を示すに拘らず他にみるべき 脑幹症状もなく OKP に図21 に示す如き脳幹小脳障害 型を示したことは，まことに注目すべきことと云わさる を得ない，即ち現在の神経学的検査法にその所見のあら われない障害がいわゆる Silent area にあつて眼振系 にのみ所見があらわれたと考えるならば大へん與味深い むのであろら. 又症例 326一23 の如く現病歴, 左右注視 眼振, 神経学的所見, その他の所見より脳幹小脳障害を
疑わせる症例で OKP が図 24 に示す通り中枢型を示し たことは前記の中枢障害所見を裏付けるものであり意義 深いものと考光る. 勿論眼振所見と同様に OKP 所見 も他の総合的検查所見の一助としてみるべきことは云う までもないがその診断的価值は高いものと云うことがで きる. OKP も含めて眼球運動の更に詳細な検討とその 診断的意義については今後の発展がのぞまれる.

\section{次に視性運動性後眼振 (OKAN) について 考察 して} みよう.

この検查も切替・鈴木 ${ }^{41)}$ によつてはじめられ五島 42) が OKAN に対する諸種薬物の 影響を 検討し小松崎が 引続き多くの症例について倹討している問題である. 突 発性恥平衡覚障害について，OKAN を行なつた結果を 表 9 に示した. 左右差のあるもの即ちどちらかの方向に 眼振の出易いものは 35 例でありこれは自発眼振のある 場合はもちろんの事, 潜在性眼振の DP 方向を示すもの
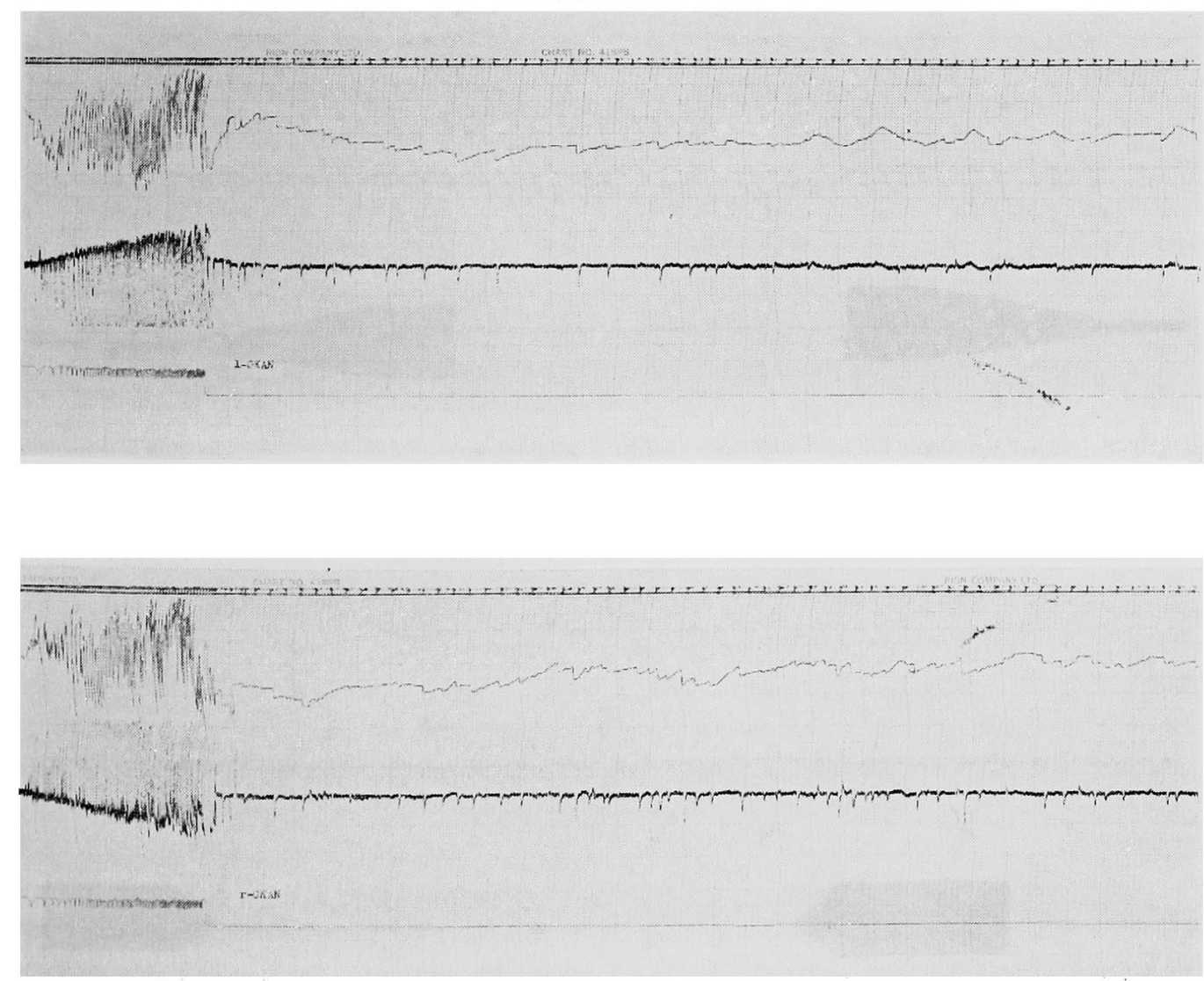

右 OKAN, 左 OKAN 共に左に眼振が出易い 
である．この皆合 DP とは一方何に限振の出易い状態 として欵つた，例党ば狭義の自発眼振はない場合でも頭 位眼振乃至は頭位变換眼振がどちらかの方向に認められ る場合，あるいは疑わしい場合 OKAN を行なつてみ ると明らかに左右差を示すことが多い，症例 255-64の 如く頭位变換検查でわずかに左に向う4〜5回の腿振が 認められる上らな場合でも図6に示す如く OKANで明 らかに左に向う DP 所見を示している。この事は回転 検査の左右差乃至は DP 万向と一致する゙事が多く我々 の検討でも OKAN に左右差の認められた 35 例が回転 検査の 左右差と一致していた，その典型的な 1 例を図 24, 図 25, 図 26 に示した. 従つて DP 方向のみを検討 しようとする場合には敢て回転検査を行なう必要はなく OKP に続いて OKAN を行亲ば大体事足りるのではな
いかと我々は考えている。しかし OKAN に左右差心 出ない症例むあり又 OKAN が非常に出にくい場合も あるのでこのような場合は回忶倹査の併用も必要となる であろう。

我々の臨床的経験によると OKAN が非常に出にく い場合は中枢障害の場合に多くみられるが現在断定する 段階ではなく今後の検討にまちたい．な挌 DP を問題 とする場合温度検查に和ける DP と OKAN あるいは 回転検查による DP との検討が必要となる. しかし DP に関して詳細に論ずることは本論文の趣旨ではなく邓そ の意義づけも困難なことが多いので敢て三者の比較は行 なつていない，少数例の 経铪から云えば三検查の DP は一致することが多く，又温度倹査と OKAN の DP はしぱしば一致しこれに上述した OKAN と回転榆查

\section{図 25}

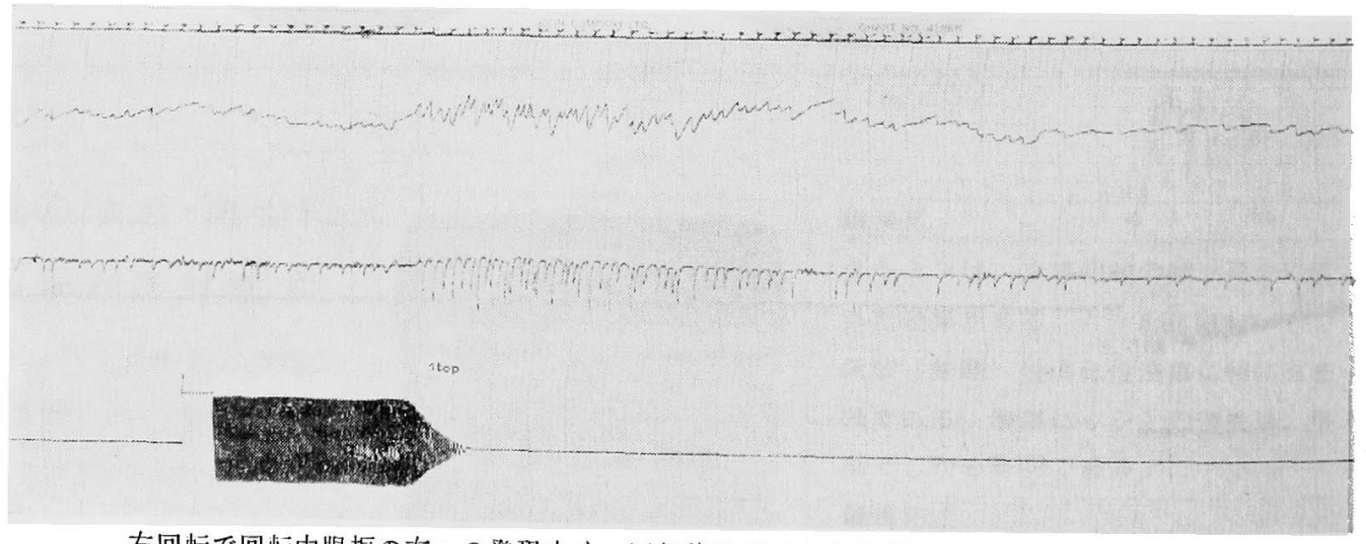

右回枟で回枟中眼振の右への発現少く，回枟後眼振で左向眼振がよく開発されている. 
の比䡆絬果を参考にすれはば温度検查, OKAN 及び回忶 愉査の DP は一致することが多いのではないかと云う ことは予想できる. 従つてこの点に関しては多くの症例 につき今後検討してみたい，

\section{回枟検査について検討してみよう.}

回転検查は表 10 亿示す如く 58 例について行ないその 中回転中眼振及び回転後眼振をらくめて左右差を認めた ものは 46 例であり右回転左回転々も眼振反応が殆んど みられず両側反応低下していると思われるものは 12 例 であつた． 即ち全例とも 異常所見を示した事は與味深 い. 左右差を認妉たのが多いのは来院後早期にしかも 何等かの形で腿振があるもの乃至は潜在性眼振があると 思われるものについて行なつたためと考兄られ当然の 結果と云党よう。回転眼振検査については Bárány 43) 以来 Egmond, Groen, Jongkees, Aschan, Nylán,
Montandon, Mittermeier 约我国に抽いては忆沃, 小倉，德增等の幾多の報告がある。德增 ${ }^{14)}{ }^{15)}$ によれば 回転中，回転後の両腿振反応をあわせて異常出現率は一 側迷路機能低下群にもつとも多いとして找り我々の結果 も又これを裹付けるものと云えよう. しかし回転検査に おける眼振反応の左右差は必ずしも患側の眼振反応低下 を示さず従つて回転検查は一側迷路機能低下側即ち患側 の決定及びその障害の程度を判定するには役立たないと 述べているが我々の検查結果でも”同様な 結論が得られ た. 又回枟眼振反応に両側反応低下が認められる場合は 両側迷路機能低下によるかあるいは一側迷路機能低下が あつて中枢による代償が行なわれた場合としている. 我々が回枟梌查を行なつた症例には両側迷路機能低下例 はなく，従つて一側迷路機能低下の場合で中枢の代償が 行なわれたと考学られ與味深い，即ち発症より経過を追

図 $\quad 26$
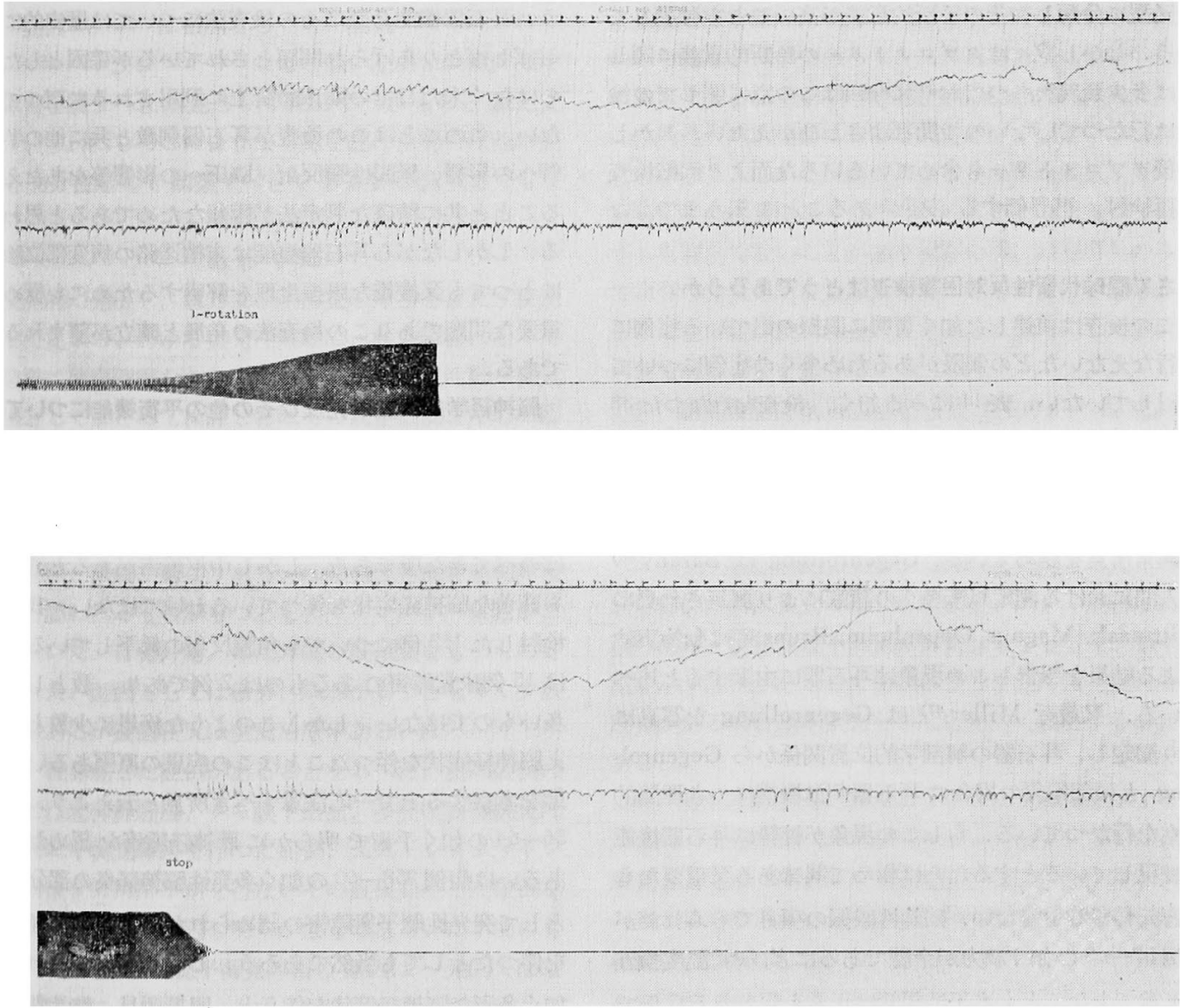

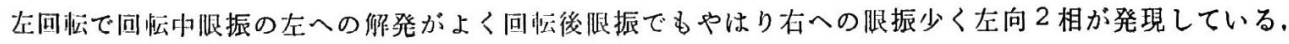


つて検査を行なうことによりとの性による代償の行な われる時期を観察することも又可能であろう．回転眼振 㭘査に左右差の認められた場合その DP 方向は自発眼 振又は潜在性眼振の向う側にある。しかし DP のみを 關題とする場合 OKAN の項目でるのべた如く回転眼 振検查の左右差と OKAN の左右差とは一致する場合 が多く敢えて回転検查を行なら必要はない上うに思う。 この実例は図 24，25，26 に示した．以上のべた如く回転 眼振検査にて異常所見を認める場合は多いが，一側迷路 機能低下症例の場合その患側の決定，障害程度の判定に は役立たず文 DP の決定も OKAN である程度事足り ることを考えれば回転検查の臨床的応用価值は少なくこ のような症例に回転検查を敢えて行なら事には大きな診 断的意味はない上うに思われた。一方朴沢 44) 46) らは Egmond, Jongkees Kよつてはじめられたクプロメト リーについて，しばしば報告しクプログラムを平行型， 交叉型に分類し，その診断的意義が高いことを強調して いる.しかし我々はクプロメトリ一の診断的意義に関し ては多少疑義をもつており又今回はこの点関しての倹 討は行なつていないので批判はさしひかえたい，しかし 今後クプロメトリーも含めていろいろな面より回転検查 る再検討，再評価する必要があることは云うまでもな w.

\section{さて眼球代償性反対回旋検查はどうであろうか．}

この検查は前述した如く著明に眼振の出ている症例に 行なえないなどの制限があるため多くの症例について 検討していない，表 11 にみる如く，検査を行なつた 33 例中約半数の 16 例が患側で低下して括りこれに0又は 不明のものを加觉ると，全例が異常所見を示している。

坂田 ${ }^{16)}$ 等む片側聴力障害例を検討し，かなりの高率 に異常所見を認めている. Gegenrollung は Bárány 46) の人間に和ける測定以来多くの諸家により測定され更に Wittmaak, Magnus, Oppenheim, Bruns 等は動物実騟 による結果を報告しこの現象は耳石器に由来すると述べ ている. 又最近 Miller 47)は Gegenrollung を写真に より測定し，耳石器の解剖学的位置関係から Gegenrollung 之頭部傾斜の場合の耳石器刺激機構につき理諭的 考察を行なつている.もしこの現象が純粋に耳石器機能 を表現しているとするならば極めて與味ある又重要なる のと云わさるを得ない，回旋性眼振の項目でるふれたが 症例 57-63 の如く聴力が全郦であるに拘らず温度検㭗 が正常で少なくとも我平半規管は正常と思われる症例で Gegenrollung が患側で低下を示し，しかも純回旋性眼
振がみられたことは注目すべき事と云えよう。少なくと も以上の所見から末梢迷路の病变が蝸牛と办平半規管を 除いた前庭迷路と云ら推定が成り立つわけである.しか し回旋性眼振については前述した如く耳石器由来説ある いは垂直半規管由来説があり，耳石器及び垂直半規管機 能檢査が確立されていない今日そのいずれとも决め難い、 のが現状である。従つて症例 57-63の如さ 場合垂直半 規管の障害があるかどうか，又あるとしたらどの程度関 与しているかなどについては推定の域を脱しないが，こ のような症例で Gegenrollung が低下していることは病 変部位診断に一つの根拠をあた劣あるのと云えないであ ろうか。更俄々の観察で健側化扣いても Gegenrollung が低下しているものが 14 例ありこれに0㕛は不明 のものを加光ると 23 例となり健側でも大部分異常所見 を示すこととなる．これを回転眼振検查の場合と同しく 中枢による代償と考えるならば注目すべき所見である 万. 耳石器機能乃至はその検査法については歴史的にも しばしばとりあげられ問題とされているが確固としたる のはなく未だ日常の臨床診断上に利用されるに至つてい ない、このことはこの検查が耳石器刺激と共に他の半规 管への影響, 緊張性頸反射, 脳王への影響等をあたえ得 ることと共に精確な判定法が困難なためであると思われ る.しかしながら耳石器機能は末梢迷路の病変部位診断 にとつても複雑な眼振生理を解明するためにる氷めて 重要な問題でありこの検查法の発展と確立が望まれる所 である。

\section{脳神経学的検查所見及びの他の平衡機能についてみ}

\section{てみたい}

笑発性㯖可衡覚障害には中枢殊飞脳幹障害を合併して いるものがあるのではないかと云ら考察は今までしばし ばのべてきた所である。しかし中枢障害があると云つて む顕著な脳神経症状を伴つているわけではない，我々の 検討した 113 例についても角膜反射の低下しているもの は15 例昧覚障害のあるものは7 例であり，数としては 多いものではない、しかしこのような疾患に少数とは云 穴脳神経症状を伴つたことはこの疾患の原因あるいは病 態を考察する上で一応注意すべき所見と云克よう，症例

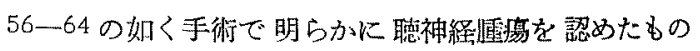
あるいは症例 258一60の如く多発性脳神経炎の部分現象 として突発性媤平衡障害の認められた場合は脳神経在状 を伴つたとしても当然であろう。しかし症例 327-62の 如く多彩な脳神経症状を伴う上，眼振所見，椎骨動脈提 影あるいは脳波所見に異常を伴うもの又症例 326-63の 
如くその脳神释症状と共に眼振むるいは OKP 新見が |枢障害を思わせるものなどがあることは與味深い。こ のような点からも突発性聴平衡覚障害は単にィ二エール 症候群として片附けられるすのでなく症例他よつては常 に中枢障害の存在を考慮に入れて経過を観察すべきもの と思5.

その他の平衡機能㭘查所見としては歩ふみ検查で異常 がみられた．即ち表 12 亿示す如く歩ふ2検查で左右転 到傾向の認められたものが 37 例であつた．末梢迷路障 害で急性発症期には平衡障害が強く，開腿足ふ久検查 で左右転倒傾向を示するのはしばしばみられる。しかし このよらな所見が急性期を過ざても相当長期間続くこ と，又症例化よては強い左右転倒傾问を示すことは， 末梢迷路障害だけでは説明しにくい事であり中枢障害の

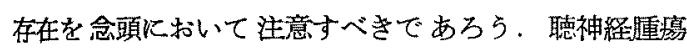
の症例 56-64 あるいは中枢障害の推定される症例 9764，症例 118一63 は当然として子，症例 291-62,327一 62, 205-63，及び326-63などの強い左右転倒㑯向は中 枢障害を疑らべき所見として注目すべきものと云克よ う、いずれルしろこのよらな所見を認めた場合は他の症 状も充分注意して観察すべきである事は云うまですな ᄂ.

おわりに

笑発的に発症し，聴力及び平衡覚の障害をさたす疾患 として従来のいわゆる笑発性難㯖に，聴力障害はなくて も急激汇前庭障害をきたす症例も加兄て突発性聴平衡覚 障害としてまとめて検討し特にその前庭機能を中心に臨 床所見をのべ更にその興味ある症例につき考察した。そ の結果次の如き所見を得た。

1. 突発性㯖平衡賞障害患者の素因として，冷え症， のぼせ症，頭痛，肩こりあるいは低血圧等血管運動障害 ありと思われるものがもつとも多くアレルギー素因がこ れに次いた．音響外傷，頭部外傷の既往歴をもつものも みられた．誘因としては疲労，風邪がもつとも多く少数 例ではあるが拔蒾後文は蜽治療中あるいはパーマドラ イヤー後発症した症例があることをのべた，更に症例の 検討では聴神経腫湯，クモ膜下出血，多発性脳神経炎に 奖発珄聴平衡覚障害を伴つた症例，又ストレプトマイシ 使用後全身麻醉手術を行ない之直後発症した症例を 報告した，そして原因の明らかなるのあるい、不明のる

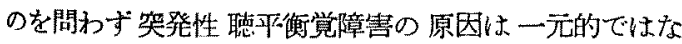
く，各症例により夫ネいるいるな原因が考光られること を推察した

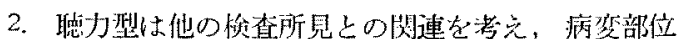

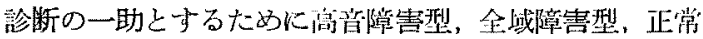
型に分证た。

3. 全例 113 例中何等かの形で眼振を認めたものは 91 例であつた。このような疾患に前庭機能検查の 1 つとし て眼振検查を行ならことは必要不可欠の牙であり何らか の自発ならびに誘発眼振老証明することは前庭系の異常 を知る他営的所見として重要な意嶬がある．とくに発症 から多少時閒を経過していて子頭位腿振，頭位变換眼振 梌查に異常の認められる場合が多く服振の性貿も多彩な 所見を示し病気乃至は病变部位診渐に有力な根拠となり 得る。限振检查の結果, 聴力障害のない急性前庭障害例 の大部分が方向一定性水平性眼振を示し，又一般に末松 迷路疾患之考兄られている突発性恥平衡覚障害に，中枢 障害に特徽的と云われる左右注視眼振，万向交代性頭位 眼振、垂直性眼振を示す症例がしばしばみられた。この ような眼振を認めた場合，一応中枢障害の存在を念頭に 扒いて注意すべきであろら，又耳石器乃至は垂直半規管 に由来すると云われる純回旋性 眼振症例もみられた。 この所見も末梢迷路に拈ける病変部位を推定する場合参 考となろう。しかし反面このような多彩な腿振所見にも 拘らずその性質をよく分析してみるとその意義づけは必 ずしも容易でないことがあり現在の所，眼振所見のみに て病変の性質や所在を彰断するにはな拈多くの困難があ るので他の症状及び検查所見を充分に参考にして検討す べきであることを述べた。

4. 温度検査の結果は CP を示するのが $71 \%$ であり 病変の広さを物語る。この検査は病变の程度及び部位診 断にとつて重要であり又この検査に無反応の症例は，聴 神経腫瘍との鑑別診断仁注意を払うべきである。

5. 視性運動性眼振は特に OKP としてとらえる時, 病変部位診断比役立つので眼振検查と同じく重要な检僸 法である，突発性聴平衡覚障害例にも中枢型及び潐中枢 型を示寸症例があるので他の検查で中枢障害を疑わせる 所見がある場合は本检查を併せ行なつて检討する必要が ある。

6. 視性運動性後眼振（OKAN）は左右差を示严もの が多い，回忶検查でも左右差を示すものが多いが DP 所見としては OKAN の左右差と回転検查の左右差は 一致寸るものが多い，一方回枟検查は患側の決定，病要 の程度の診断には役に立たず臨休的に用いるには価值が 少いので DP のみを対象とする塨合 OKAN 検査で事 足りる場合の多いことを述へた。 


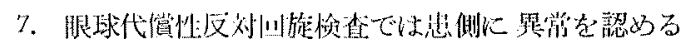
ことが多く、もしこの現象が純粋に耳石器に由来するも のとすれば病变部位部断及び腿振発現機構の解明に役立 つあのである。しかし本検查及びその意味的けに関して は今後の検討记待つことが多い．

8. 脳神経学的所見及びその他の平衡機能検查所見に む中枢障害を思わせる所見を示す例があり，他の检查所 見と共に充分注意して検討すべきであることを述べた。

9. 與味ある症例の検討として原因の確定又は推定で きるもの，比較的動機のはつきりしているもの，及び原 因不明のものに分けて提示し各症例に認められた所見の 意義について検討と考察を行なつた。

10. 以上の諸点上り 突発性聴平衡覚障害の 原因と病 態像につき考察を加兄, 本疾患に関しては秱牛機能検査 のみでなく上記の如き各種の前庭機能検查更に症例に上 つては脳血管撮影，脳波等の検查を行うことに上り従来 よりな㧍詳細に末梢迷路子至中枢に拈ける病変の範囲を 推定しらることを述べた，又それにより，本疾患の中に は中枢に原因を有する症例のあるものを発見し得ること を指摘した。

\section{主要文献}

1) 野末道虔他：末梢逃路疾患儿関寸万䠛床的研究， その 1，前庭迷路症状とくに眼振を中心にみた突発難婹 の病像，耳堠科，35,11,901，1963，2）切替一郎他: Sudden Deafness の罣力型について，耳㬋科，35, 6, 437, 1963. 3) 切替一郎他: Sudden Deafness の病 变部位一と々飞㙏觉之前庭機能との関連について, 耳㬋 科，36，3，213，1964。4）村上元孝, 上田泰：低血

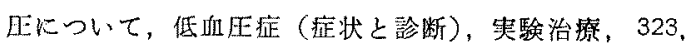
1 4, 1959.5）切替一郎，圾田英治：自発並に嵊 発腿振検查法 (印刷中).

6) Fitzgerald, G. \& Hallpike, C.S.: Observations on the Directional Preponderance of Caloric Nystagmus resulting from Unilateral Labyrinthectomy. Brain, 65, 115, 1942.

7) 猪初舅，早川富之助：浅路機能検查法としての Caloric Test の吟味, 耳涘科, 23, 9, 367, 1954.

8) Jongkees, L.B.W: Which is preferable method of performing the caloric test. Archives of otolaryng. 49, 594, 1949.99)鉿木淳一他: 視性邁助性艮 振の臨床的応用一OKPテストについて一，日耳率，64， $120,1422,1960$, 10）鈴木涼一他：Clinical application of optokinetic nystagmus-Optokinetic Pattern Test, Acta otolaryng. 54, 49, 1961. 11) “小炂崎䈍:

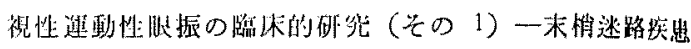

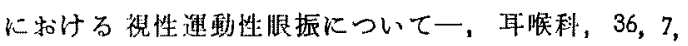
619, 1964.12）小松崎䉆他： Electronystagmography. 内科, 14, 5, 853, 1964. 13) 小松崎篤：视性 運動性腿振の臨床的研究（その2）テント下疾患とくに

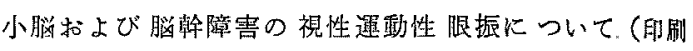
中）. 14）徳增厚二：前庭機能揄查に和ける回転中 ならびに回枟後眼振の检討，日耳蒋，65，1，8，1962。 15）镘增厚二他：回転眼振検查の㛟討一之くにその誩 断意義について一，耳界臨，54，11，1961。16）坂田

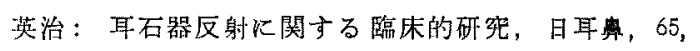

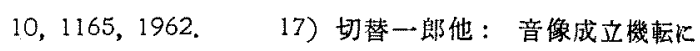
関寸る基礎的研究之臨床的応用，オージオロジ一別冊， 7, 1, 1964, 18) Dix, M.R. \& C.S. Hallpike: The Pathology, Symptomatology and Diagnosis of Certain Common Disoders of the Vestibular System. Ann. Otol. 61, 987, $1952 . \quad 19)$ H. Ganz: Plötzliche Ausfälle der Lahyrinthfunktion. HNO, Band 9, 1, 7, 1961.20$)$ A.B. Bosatra \& G.B. De Stefani: Idiopathic sudden deafness- a clinical study-. Acta otolaryng. snppl., 169.21 ) 山崎芳樹：笑発性奞 聴, 耳鼻䠦, 56, 5, 235, 1936 . 22) Harod F. Schuknecht: The Pathology of Sudden Deafness. Laryngoscope, 9, 1142, 1962。 23) 龟山正邦: 项 部拉上び脳動脈硬化と脳血管障害，日本臨床，22，7，

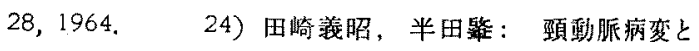
腷血管障害, 日本臨床, $22,7,41,1964.25)$ 岈 末道济他: 末梢迷路疾患の自律神経機能 (印刷中). 26) 久木元正延： ストレプトマイシンの侅器に及注す 影響に就ての実験的研究, 耳丼隐，48,.573, 1955，27) 千葉信：Dihydrostreptmycin 髄腔内注射の聴器並び に平衡器に及ぼす影響に関する実験的研究, 耳舞潞, 54，323，1961，28）田辺等：Mecholyl Test Kつ いて，第9回小先起立性調節障害研究会，1962。29) Nylen, C.O: A clinical study on positional nystagmus in cases of brain tumor. Acta otoloryng. Stockh. suppl., 33, 1, 1939. 30) 坂田英治：中极坐 疾患ことにテント下疾患に拔ける眼振の診断的意䔐一小 脳橋角腫境を主とする自発眼振 (広莪) を中心に一, 耳 娭科，34, 9, 735, 1962. 31) Fernàndez, C. Alzate, $R$ \& Lindsay, $R:$ Experimental Observation on Postural Nystagmus in the Cat. Ann. Otol., 68, 816, 1959. 32) Jongkees, L.B.W.: On positional 
nystagmus. Acta otolaryng. suppl., 159, 78, 1960. 33) Ruttin, E,: Über Lageschwindel und Schwindel-Lage. Mschr. Ohren-heilk. 70, 257, 1936. 34) 圾田英治他：濒位变化時にあらわれる眼振（頭位变化 艮振）火関する砳究，耳噍科，34,1,13,1962。35)铪 橸一他: Compensatory Eye Movements Induced by Vertical Semicircular Canal Stimulation. Experimental neurology, 9, 137, 1964. 36) Fürstner, I \& Kralovansky: Vertical nystagmus cases of peripheral origin. Zbl. Hals, Nas-u ohrenheilk., 69, 249, 1961. 37) Svane-Knudsen: Sudden "Spontaneous" Lesion of Aural Funktion. Acta otoloryng., 47, 270, 1957. 38) Bernard Cohen et all: Eye movements from semicircular canal nerve stimulation in the cat. Ann. Otol., 73, 153, $1964 . \quad 39)$ Bàrány, R: Zur Klinik und Theorie des Eisenbahnnystagmus. Acta otolaryng., 3, 260, 1920.40 ) De Kleyn, A.. Sudden complete or partial loss of function of the octavussystem in apparently normal person. Acta otolaryng., 32, 407, 1944. 41) 切替一郎他: Spontaneous Nystagmus as a Sign of Clinical Significance. Acta otolaryng. suppl. 179, 86, 1963.42$)$ 五島一吉他：末梢前庭性眼振に及注 与徸種薬物の影響—視性運動性腿振を中心として一， 日耳年，66,11，1351，1963. 43) Báràny, R:

Weitere Untersuchungen über den von Vestibularapparat des ohres reflektorisch ausgelösten. rhyth- mischen Nystagmus und seine Begleiterscheinungen. Mschr. ohrenheilk. 41, 477, 1907 44) 朴沢二邚:

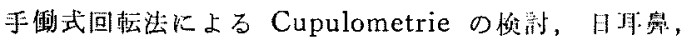

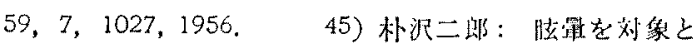
Lた “Vestibular Asymmetry”の臨林的研觉，日开 舆, 64, 6, 1141, 1961. 46) Barány, $R$ : Über die vom ohrlabyrinth ausgelöste Gegenrollung der Augen bei Normal hörenden und Taubstummen. Archin f. ohren-u.s.w. heilk., 68, 1, 1906. 47) Earl F. miller II: Counterrolling of the Human eyes produced by Head tilt with respect to gravity. Acta otolaryng., 54, 479, 1962.

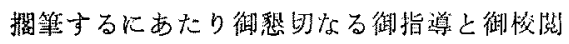

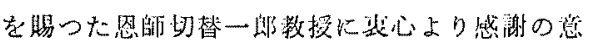
を表する。

あわせて本研妴に終始御招力下さつた领木湿 一博士，德增掌二博士，呫田奖治博士，五島一 吉学士, 小松㱦第博士, 攧戸口寿一学士, 上田 良䅹学士ならびに教室員各位に心から礼を礼を し上げる。

な括本論文の一部は炤和 38 年12月5日第 404 回日本耳舜咽喉料学会関東地力会及び北和 39 年 11 月 18 日第16回日本前庭研究会に扔い て発表した。

（原稿到着 $=$ 昭和 39.12.23日） 